\title{
Molecular mimicry between streptococcal pyrogenic exotoxin B and endothelial cells
}

\author{
Yueh-Hsia Luo, ${ }^{1,2}$ Woei-Jer Chuang ${ }^{3}$, Jiunn-Jong Wu ${ }^{4}$, Ming T Lin ${ }^{3}$, Ching-Chuan Liư ${ }^{5}$ Pao-Yen Lin ${ }^{6}$, \\ Jun-Neng Roan ${ }^{6}$, Tak-Wah Wong ${ }^{7}$, Yuh-Ling Chen ${ }^{8}$ and Yee-Shin Lin ${ }^{1,2,9}$
}

Molecular mimicry between group A streptococcus and host antigens has important roles in the development of poststreptococcal sequelae, including glomerulonephritis and rheumatic heart disease (RHD). The etiology of RHD involves host cross-reactivity with $M$ proteins and carbohydrate antigens. In this study, we show that anti-streptococcal pyrogenic exotoxin B (SPE B) antibodies exhibited characteristics of autoantibodies, which cross-react with endothelial cells. Immunoglobulin G (IgG) deposition and complement activation were observed in the heart valve of SPE B-immunized mice. In addition, apoptosis in the heart valve was detected in SPE B-immunized mice. An anti-SPE B monoclonal antibody (mAb) 10G showed cross-reactivity with human microvascular endothelial (HMEC-1) cells and mouse valve endothelial cells. Passive immunization with $\mathrm{mAb} 10 \mathrm{G}$ also caused IgG deposition, complement activation, and apoptotic cell death in the mouse heart valve. We conducted peptide array and ELISA using synthetic peptides to identify the SPE B antigenic epitope recognized by $\mathrm{mAb} 10 \mathrm{G}$. Results showed that the major epitope of $\mathrm{mAb} 10 \mathrm{G}$ is localized to amino-acid residues 296-310 of SPE B (P7-8). The cross-reactivity of mAb 10G with endothelial cells was inhibited using P7-8 peptides for competition. These results suggest that anti-SPE $B$ antibodies cross-react with endothelial cells, and that a dominant epitope is located within the amino-acid residues 296-310 of SPE B. Moreover, we found that mAb 10G can also bind to $N$-acetyl- $\beta$-D-glucosamine (GlcNAc) conjugated with bovine serum albumin (BSA), but not to BSA or M1 protein. Competition assay showed that the binding activity of mAb 10G with GlcNAc-BSA and P7-8 of SPE B was inhibited by pretreatment with GICNAc-BSA or P7-8 peptides. Therefore, our results suggest that conformational molecular mimicry may exist between SPE B and GlcNAc.

Laboratory Investigation (2010) 90, 1492-1506; doi:10.1038/labinvest.2010.93; published online 10 May 2010

KEYWORDS: autoantibodies; epitope; group A streptococcus; rheumatic heart disease; streptococcal pyrogenic exotoxin B

Group A streptococcus (GAS) is an important Gram-positive human pathogen. The clinical outcomes range from mild throat and skin infections, such as pharyngitis and impetigo, to severe and even life-threatening invasive diseases, including necrotizing fasciitis and streptococcal toxic shock syndrome. Immune-mediated post-infectious sequelae, such as acute rheumatic fever and post-streptococcal glomerulonephritis may also occur. ${ }^{1-4}$ Some unresolved aspects of GAS infection include the resurgence of severe GAS-related diseases and the pathogenesis of post-infectious sequelae. ${ }^{5}$ Increased knowledge of the mechanisms underlying GAS pathogenesis will help to enhance diagnostic and therapeutic progress and vaccine development. ${ }^{6-8}$

Acute rheumatic fever is characterized by inflammation of the joints (arthritis), heart (carditis), central nervous system (chorea), skin (erythema marginatum), and subcutaneous nodules. $^{9-11}$ Rheumatic heart disease (RHD) represents the serious sequelae of acute rheumatic fever, and remains a great global burden of disease caused by GAS. ${ }^{1-3}$ Numbers of cases of RHD have been underestimated using clinical diagnosis as compared with systematic screening with echocardiography. ${ }^{12,13}$ Risk factors for RHD include immunogenetic

\footnotetext{
${ }^{1}$ Institute of Basic Medical Sciences, National Cheng Kung University Medical College, Tainan, Taiwan; ${ }^{2}$ Department of Microbiology and Immunology, National Cheng Kung University Medical College, Tainan, Taiwan; ${ }^{3}$ Department of Biochemistry and Molecular Biology, National Cheng Kung University Medical College, Tainan, Taiwan; ${ }^{4}$ Department of Medical Laboratory Science and Biotechnology, National Cheng Kung University Medical College, Tainan, Taiwan; ${ }^{5}$ Department of Pediatrics, National Cheng Kung University Medical College, Tainan, Taiwan; ${ }^{6}$ Department of Surgery, National Cheng Kung University Medical College, Tainan, Taiwan; ${ }^{7}$ Department of Dermatology, National Cheng Kung University Medical College, Tainan, Taiwan; ${ }^{8}$ Institute of Oral Medicine, National Cheng Kung University Medical College, Tainan, Taiwan and ${ }^{9}$ Center for Gene Regulation and Signal Transduction Research, National Cheng Kung University, Tainan, Taiwan Correspondence: Dr Y-S Lin, PhD, Department of Microbiology and Immunology, National Cheng Kung University Medical College, 1 University Road, Tainan 701, Taiwan. E-mail: yslin1@mail.ncku.edu.tw
} 
differences, MHC antigens, and immune responses against host and streptococcal antigens. ${ }^{11,14-17}$ Both B- and T-cell responses are involved in the molecular mimicry and pathogenesis of RHD., ${ }^{9-23}$ A two-hit hypothesis indicates that antibodies have a role in the initiating step of the disease at the valve endothelium, followed by T-cell infiltration through the activated endothelium into the valve. ${ }^{9}$ Anti-streptococcal antibodies have been shown to cross-react with cardiac myosin, tropomyosin, laminin, and vimentin; these crossreactive antibodies recognize the $\mathrm{M}$ protein or the group $\mathrm{A}$ carbohydrate $N$-acetyl-glucosamine (GlcNAc) ${ }^{9,18,24-27}$

Streptococcal pyrogenic exotoxin B (SPE B) is a cysteine protease, which cleaves various host factors. ${ }^{1}$ SPE B and its zymogen precursor have been suggested to function as a nephritogenic antigen. ${ }^{28-31}$ The presence of SPE B was detected in kidney biopsies of patients with post-streptococcal glomerulonephritis. $^{32,33}$ In addition, anti-SPE B/zymogen titers were more consistently increased in patient sera than antibody titers to other GAS antigens, such as glyceraldehyde-3-phosphate dehydrogenase, streptolysin $\mathrm{O}$, and DNase B. ${ }^{32,34}$ Using a mouse model, we previously showed that anti-SPE B antibodies are involved in the pathogenesis of glomerulonephritis. One particular anti-SPE B monoclonal antibody (mAb) clone, 10G, can cross-react with the kidney endothelium and cause kidney injury. ${ }^{35}$ In this study, we investigated the possible role of anti-SPE B antibodies in the pathogenic mechanisms of RHD. We used the mouse model of active immunization with recombinant SPE B or passive immunization with $\mathrm{mAb} 10 \mathrm{G}$ and found pathological effects of anti-SPE B antibodies in the heart. mAb 10G was found to cross-react with human microvascular endothelial (HMEC1) cells and mouse valve endothelial cells. We also identified the epitope recognized by anti-SPE B mAb. We found that mAb 10G can bind to amino-acid residues 296-310 of SPE B $(\mathrm{P} 7-8)$ and to carbohydrate antigen GlcNAc, suggesting the existence of antigenic similarity between SPE B P7-8 and GlcNAc.

\section{MATERIALS AND METHODS Preparation of Recombinant SPE B, C192S, and Other Mutants}

Recombinant SPE B and C192S were prepared as described previously. ${ }^{36,37}$ Briefly, the genomic DNA of GAS was extracted and the pro-SPE B gene was amplified by PCR using the sense primer $5^{\prime}$-GGATCCGGATCCCATCATCATCAT CATCATGATCAAAACTTTGCTCGTAACGAA- ${ }^{\prime}{ }^{\prime}$ with a His $_{6}$ tag and $B a m \mathrm{H} 1$ restriction site and by the antisense primer 5'-GGATCCGGATCCCTAAGGTTTGATGCCTACAACAG-3' with $B a m \mathrm{H} 1$ restriction site. The PCR product was purified and then cloned into the BamH1 site of the pET-21a vector. The recombinant plasmid was transformed into Escherichia coli BL21(DE3)pLys strain, under the control of a strong T7 promoter. The wild-type construct was further used to produce Q102N, C192S, G281A, G308S, V334A, and W357A mutants using overlap extension PCR. The recombinant proteins were produced by growing cells at $37^{\circ} \mathrm{C}$ for $6-8 \mathrm{~h}$ in LB medium containing $10 \mathrm{~g} / \mathrm{l}$ Bacto-tryptone, $5 \mathrm{~g} / 1$ Bactoyeast extract, and $10 \mathrm{~g} / \mathrm{l} \mathrm{NaCl}$. The cell culture was further added with isopropyl-1-thio- $\beta$-D-galactopyranoside $(1 \mathrm{mM}$; Sigma-Aldrich, St Louis, MO, USA) and incubated at $15-37^{\circ} \mathrm{C}$ for $2-24 \mathrm{~h}$ to induce protein production. These proteins were then purified using $\mathrm{Ni}^{2+}$-chelating chromatography (Amersham Biosciences, Uppsala, Sweden). The $40-\mathrm{kDa}$ C192S protein was concentrated by Amicon ultrafiltration with $10-\mathrm{kDa}$ cutoff membrane and exchanged with phosphate-buffered saline (PBS). The $28-\mathrm{kDa} \mathrm{C} 192 \mathrm{~S}$ was obtained from the 40-kDa C192S mutant zymogen after cleavage with trypsin. On the basis of the circular dichroism and NMR analyses, the C192S mutant exhibited the same secondary structures as wild-type SPE B. ${ }^{36}$

\section{Immunization Protocol}

$\mathrm{BALB} / \mathrm{c}$ breeder mice were purchased from Jackson Laboratories (Bar Harbor, ME, USA) and were maintained on standard laboratory food and water ad libitum in our medical college laboratory animal center. Their 8-week-old progeny were used in this study. Mice were intraperitoneally injected with $50 \mu \mathrm{g}$ of $28-\mathrm{kDa}$ recombinant SPE B mutant C192S in complete Freund's adjuvant and then administered two immunizations of C192S $(50 \mu \mathrm{g})$ in incomplete Freund's adjuvant every 2 weeks. The fourth immunization was an intravenous injection of C192S $(10 \mu \mathrm{g})$. The mice were killed 8 days later. Mice immunized with bovine serum albumin (BSA; Sigma-Aldrich) were the controls. There were five mice in each group.

\section{Generation of Anti-SPE B mAbs}

$\mathrm{BALB} / \mathrm{c}$ mice were immunized as described above and killed 4 days after the last injection. Western blotting verified that the anti-C192S mAb clones 10G and 9C (derived from mice immunized with 28-kDa C192S) and 1-64.1 (derived from mice immunized with $40-\mathrm{kDa} \mathrm{C} 192 \mathrm{~S}$ ) recognized both wildtype SPE B and C192S mutant. Three mice per group were intravenously immunized with $500 \mu \mathrm{g}$ of $\mathrm{mAb} 10 \mathrm{G}$ or $9 \mathrm{C}$ immunoglobulin G (IgG) for 3 days and killed after 7 days.

\section{Immunohistochemistry Staining}

The mouse heart tissue was fixed in $10 \%$ neutral-buffered formalin solution and then dehydrated in graded alcohol. The fixed tissue was embedded in paraffin and sliced into 4-mm-thick sections. The heart tissue sections were deparaffinized and then heat-induced antigen retrieval was performed by microwaving twice at $800 \mathrm{~W}$ for $5 \mathrm{~min}$ in $0.01 \mathrm{M}$ citric acid ( $\mathrm{pH} 6.0$ ), followed by slow cooling for $20 \mathrm{~min}$. The heart tissue sections were incubated with Proteinase $\mathrm{K}$ in TE buffer $\left(50 \mathrm{mM}\right.$ Tris- $\mathrm{HCl}, 1 \mathrm{mM}$ EDTA, $5 \mathrm{mM} \mathrm{CaCl}_{2}, 0.5 \%$ Triton $\mathrm{X}-100, \mathrm{pH} 8.0$ ) for $20 \mathrm{~min}$ at room temperature. These heart sections were treated with $0.3 \% \mathrm{H}_{2} \mathrm{O}_{2}$ in water to inhibit endogenous peroxidase activity, followed by antigen retrieval. The tissue sections were blocked using $10 \%$ BSA in 
PBS. Adequately diluted primary antibodies in antibody diluents (Dako Corporation, Carpinteria, CA, USA) were applied to the sections and incubated at $4^{\circ} \mathrm{C}$ overnight. The sections were washed in $0.05 \%$ PBS-Tween 20 (PBST) and then incubated with horseradish peroxidase (HRP)-labeled secondary antibodies at room temperature for $1 \mathrm{~h}$. After being washed with PBS, the tissue sections were developed using the DAB substrate kit (Vector Laboratories, Burlingame, CA, USA) and viewed with light microscopy. IgG deposits were detected using HRP-conjugated goat anti-mouse $\operatorname{IgG}$ (Jackson Immunoresearch Laboratories, West Grove, PA, USA). Complement C3 was detected using sheep anti-human C3d (Serotec, Oxford, UK), which cross-reacts with mouse C3d, followed by HRP-conjugated goat anti-sheep IgG (Jackson Immunoresearch Laboratories).

Normal mouse heart tissues were fixed with 3.7\% formaldehyde for $24 \mathrm{~h}$ and deparaffinized, after which the tissue sections were incubated in $0.01 \mathrm{M}$ citric acid $(\mathrm{pH} 6.0)$ at $95^{\circ} \mathrm{C}$ for $20 \mathrm{~min}$. The tissue sections were blocked using 10\% BSA in $\mathrm{PBS}$, and then $1 \mathrm{M} \mathrm{NH}_{4} \mathrm{Cl}$ was used to reduce autofluorescence. Adequately diluted mAbs $10 \mathrm{G}$ and $9 \mathrm{C}$ in antibody diluents (Dako Corporation) were then applied to the tissue sections and incubated at $4^{\circ} \mathrm{C}$ overnight. Double immunofluorescence staining with anti-SPE B and anti-CD31 was performed using $\mathrm{mAb} 10 \mathrm{G}$ or $9 \mathrm{C}$ and rat anti-mouse CD31 (Serotec), followed by tetramethyl rhodamine isothiocyanate-conjugated goat anti-mouse IgG and fluorescein isothiocyanate (FITC)-conjugated goat anti-rat IgG (Jackson Immunoresearch Laboratories), respectively. The tissue sections were observed by fluorescence microscopy.

\section{TUNEL Assay}

To detect apoptotic cells in the formalin-fixed heart tissue, a terminal transferase dUTP nick-end labeling (TUNEL) assay was conducted using the ApopTag plus fluorescein in situ apoptosis detection kit (Chemicon International, Temecula, CA, USA). TUNEL labeling was visualized under fluorescence microscopy.

\section{Cell Culture}

HMEC-1 was obtained from the Centers for Disease Control and Prevention (Atlanta, GA, USA) ${ }^{38}$ and cultured in Medium 200 (Cascade Biologics, Portland, OR, USA) supplemented with $2 \%$ fetal bovine serum, $1 \mu \mathrm{g} / \mathrm{ml}$ hydrocortisone, $10 \mathrm{ng} / \mathrm{ml}$ epidermal growth factor, $3 \mathrm{ng} / \mathrm{ml}$ basic fibroblast growth factor, $10 \mu \mathrm{g} / \mathrm{ml}$ heparin, and antibiotics.

\section{Extraction of Endothelial Cell Membrane Proteins}

HMEC-1 cells were washed in PBS and scraped in $1 \mathrm{ml}$ of homogenization buffer $(320 \mathrm{mM}$ sucrose, $50 \mathrm{mM}$ Tris- $\mathrm{HCl}$, $2 \mathrm{mM}$ EDTA, $5 \mathrm{mM} \mathrm{MgCl}_{2}, \quad 50 \mu \mathrm{M}$ PMSF, $20 \mu \mathrm{g} / \mathrm{ml}$ leupeptine, and $2 \mathrm{mM}$ EGTA). After a 30-min incubation on ice, the cells were disrupted in a Dounce homogenizer and centrifuged at $435 \mathrm{~g}$ for $10 \mathrm{~min}$. The supernatant was then centrifuged at $100000 \mathrm{~g}$ at $4^{\circ} \mathrm{C}$ for $30 \mathrm{~min}$. The pellet was resuspended in $1 \%$ Triton X-100 homogenization buffer and incubated on ice for $50 \mathrm{~min}$. After centrifugation at $100000 \mathrm{~g}$ for $30 \mathrm{~min}$, the endothelial membrane proteins (EMPs) were collected from the supernatant.

\section{Flow Cytometry}

HMEC-1 cells were fixed with $1 \%$ formaldehyde in PBS at room temperature for $10 \mathrm{~min}$. The cells were adjusted to $5 \times 10^{5}$ per tube, and incubated with mAb 10G, 9C or 1-64.1, or control mouse IgG at room temperature for $1 \mathrm{~h}$. After three washes with PBS, cells were incubated with FITCconjugated anti-mouse IgG for $1 \mathrm{~h}$ at $4^{\circ} \mathrm{C}$ and then analyzed by flow cytometry (FACSCalibur; BD Biosciences, San Jose, CA, USA).

\section{Synthesis of GIcNAc Conjugated with BSA}

GlcNAc conjugated with BSA was conducted in a two-step reaction, ${ }^{39}$ with 5:1, 10:1, and 50:1 molar ratios of GlcNAc to BSA. Briefly, $P$-aminophenyl-2-acetamido-2-deoxy- $\beta$-D-glucopyranoside (Sigma-Aldrich) was activated by an equimolar amount of glutaric dialdehyde in $0.1 \mathrm{M} \mathrm{Na}$-carbonate buffer, $\mathrm{pH} 9.0$, for $30 \mathrm{~min}$ at $20^{\circ} \mathrm{C}$, and then mixed with BSA in the same buffer. The mixture was incubated for $1 \mathrm{~h}$ at $20^{\circ} \mathrm{C}$ with subsequent dialysis against $0.05 \mathrm{M}$ Tris- $\mathrm{HCl}$ buffer, $\mathrm{pH}$ 8.5. GlcNAc-BSA was eluted from a DEAE column (Amersham Pharmacia, Piscataway, NJ, USA) using an $\mathrm{NaCl}$ gradient $(0.05,0.1,0.2,0.3$, and $0.5 \mathrm{M} \mathrm{NaCl})$ in $0.05 \mathrm{M}$ Tris- $\mathrm{HCl}, \mathrm{pH}$ 8.5. The GlcNAc-BSA conjugate was confirmed by the binding of biotinylated WGA (Vector Laboratories) with subsequent detection of lectin binding by avidin-peroxidase. Biotinylated WGA specifically reacted with GlcNAc-BSA but not BSA. The anti-GlcNAc-BSA sera were generated by active immunization of mice with GlcNAc-BSA (50:1) twice every 2 weeks, and the titers were measured using ELISA.

\section{ELISA}

To determine the dose responses of $\mathrm{mAb} 9 \mathrm{C}$ and $10 \mathrm{G}$ reactive with C192S, P7-8 peptides, EMP, GlcNAc-BSA, BSA, and SPE A (obtained from YH Lu, Department of Microbiology and Immunology, National Cheng Kung University Medical College, Tainan, Taiwan), the ELISA plates were coated with $100 \mu \mathrm{l}$ per well of $10 \mu \mathrm{g} / \mathrm{ml}$ of each antigen for $2 \mathrm{~h}$ at $37^{\circ} \mathrm{C}$, and then blocked with $10 \%$ BSA in PBS at $4^{\circ} \mathrm{C}$ overnight. After washing with $0.05 \%$ PBST, serial dilutions of $\mathrm{mAb} 9 \mathrm{C}$ and $10 \mathrm{G}$ were added and incubated at $4^{\circ} \mathrm{C}$ overnight. After three washes with $0.05 \%$ PBST, HRP-conjugated anti-mouse IgG (1:5000 dilution) was added for $2 \mathrm{~h}$ at $37^{\circ} \mathrm{C}$. After washing with $0.05 \%$ PBST and incubation with $3,3^{\prime}, 5,5^{\prime}$-tetramethylbenzidine, the absorbance was measured using an Emax microplate reader (Molecular Devices, Sunnyvale, CA, USA) at $450 \mathrm{~nm}$.

\section{Peptide Array}

In all, 16 synthetic peptides in one nitrocellulose array, each containing 10 amino-acid residues from 266 to 350 of SPE B, 
were prepared by Genesis Biotech (Taipei, Taiwan). The peptides were directly synthesized in situ on nitrocellulose paper as described previously. ${ }^{40,41}$ The nitrocellulose membrane was blocked with $5 \%$ gelatin in Tris-buffered salineTween 20 (TBST) for $2 \mathrm{~h}$ at room temperature, followed by three washes. After incubation with mAb $10 \mathrm{G}$ for $2 \mathrm{~h}$ and three washes, HRP-conjugated anti-mouse IgG in $0.5 \%$ gelatin/TBST was added and incubated. After further three washes, enhanced chemiluminescence (ECL) solution (Western Lightning kit; Perkin-Elmer Life Sciences, Boston, MA, USA) was added and developed using BioMax light film (Eastman Kodak, Rochester, NY, USA).

\section{Peptide Competitive Inhibition}

mAb 10G $(1 \mu \mathrm{g})$ was incubated with $5,10,20$, or $40 \mu \mathrm{g}$ of C192S, synthetic peptides, GlcNAc-BSA, or BSA for $1.5 \mathrm{~h}$ at room temperature. The supernatants were collected after centrifugation at $13000 \mathrm{~g}$ for $15 \mathrm{~min}$. The supernatants were then incubated with HMEC-1 cells for cell-binding assay using flow cytometric analysis or were added to the ELISA plate coated with C192S, synthetic peptides, or GlcNAc-BSA for detection of antibody-binding activity. Synthetic peptides of P4-5 (amino-acid residues 281-295, $\mathrm{N}^{\prime}[\mathrm{H}]-$ GSAGSSRVQRALKEN-C'[OH]), P7-8 (amino-acid residues 296-310, $\mathrm{N}^{\prime}[\mathrm{H}]-$ FGYNQSVHQINRGDF-C' $\left.[\mathrm{OH}]\right), \quad$ P9-10 (amino-acid residues 306-320, $\mathrm{N}^{\prime}[\mathrm{H}]$-NRGDFSKQDWEAQID-C' $[\mathrm{OH}]$ ), P14-15 (amino-acid residues 331-345, $\mathrm{N}^{\prime}[\mathrm{H}]$-YQGVGKVGGHAFVID-C' $[\mathrm{OH}]$ ), and SPEB-2 (amino-acid residues $166-177, \mathrm{~N}^{\prime}[\mathrm{H}]$-YNLLTPVIEKVK- $\left.\mathrm{C}^{\prime}[\mathrm{OH}]\right)$ were from Sigma-Genosys (Cashmere Scientific, Taiwan).

\section{Statistical Analysis}

We used one-way ANOVA, followed by Tukey's multiple comparison post test for statistical analysis. Statistical significance was set at $P<0.05$.

\section{RESULTS}

Immunoglobulin Deposition, Complement Activation, and Apoptosis in the Heart Valve of SPE B-immunized Mice

Autoimmune responses against the heart and other tissues are associated with post-streptococcal sequelae., ${ }^{4,9}$ Our previous studies have shown that anti-SPE B antibodies cross-reacted with glomerular endothelial cells and induced complement activation and cell infiltration, leading to renal injury. ${ }^{35}$ Using a mouse model, we investigated the possible role of anti-SPE B antibodies in the heart. Owing to the autocatalytic activity of SPE B, we used the protease-negative mutant C192S, which exhibits the same secondary structures as wild-type SPE $B{ }^{36}$ to immunize mice. Immunohistochemical changes appeared in the heart valve tissue of mice after they had been hyperimmunized with C192S. We found IgG and complement C3 deposits on the valve of C192S-immunized mice, but not in BSA-immunized mice (Figure 1a and $\mathrm{b}$ ).
We next checked the heart valve damage in SPE B-immunized mice by histological examination of apoptotic cell death. TUNEL-positive nuclei were observed in SPE B-immunized mice, whereas BSA-immunized mice were used as the negative control (Figure 1c).

\section{Anti-SPE B mAb 10G Binds to Endothelial Cells and Causes Immunohistochemical Changes in the Mouse Heart Valve}

We generated monoclonal anti-C192S antibodies to further investigate the role of antibodies against SPE B in endothelial cell binding. One anti-C192S mAb clone, 10G, can bind to endothelial HMEC-1 cells as detected by flow cytometric analysis (Figure 2a and b). mAbs 9C and 1-64.1 were used as negative controls. In the experiments shown in Figure 2a and b, HMEC-1 cells were fixed first before incubation with antibodies. We also incubated antibodies with cells before fixation and found similar results as those in Figure $2 a$ and $b$. Supplementary Figure 1a shows one set of representative data of mAb binding to nonfixed HMEC-1 cells. Supplementary Figure $1 \mathrm{~b}$ shows that $\mathrm{mAb} 10 \mathrm{G}$ can bind to nonfixed HMEC-1 cells dose dependently. The endothelial cell-binding activity of $\mathrm{mAb}$ 10G was also confirmed by ELISA using membrane extracts of HMEC-1 cells (Figure 2c). Immunohistochemical staining followed by confocal microscopic observation showed the cross-reactivity of mAb 10G with HMEC-1 cells (Figure 2d and Supplementary Figure 2). Colocalization of $\mathrm{mAb} 10 \mathrm{G}$ with anti-CD31 antibody confirmed the binding of mAb 10G but not $\mathrm{mAb} 9 \mathrm{C}$ to mouse heart endothelial cells (Figure 2e). As the expression of CD31 is restricted to endothelial cells, ${ }^{42}$ the mouse heart valve was stained for expression of CD31 antigens revealing the endothelial lining. Furthermore, we found $\mathrm{IgG}$ and complement $\mathrm{C} 3$ deposits on the valves of mice intravenously immunized with mAb 10G, but not in those of mice treated with mAb 9C (Figure $3 \mathrm{a}$ and $\mathrm{b}$ ). TUNEL-positive nuclei were observed in mAb 10G- but not mAb 9C-treated mice (Figure 3c). To check for the antibody effect on HMEC-1 cells, results showed that these cells may undergo apoptosis after treatment with mAb 10G (Supplementary Figure 3).

\section{Identification of the Epitope Recognized by Anti-SPE B mAb 10G}

In addition, we used $\mathrm{mAb} 10 \mathrm{G}$ to determine the recognition epitopes on SPE B. For epitope mapping, we conducted several approaches. We first used a phage display peptide library to screen for the amino-acid sequences that can be recognized by mAb 10G. By sequence alignment, we found that dominant $\mathrm{mAb}$ 10G recognition sequences were localized in SPE B amino-acid residues 266-350 (data not shown). Using an EMBOSS program to search for possible epitopes within amino-acids 266-350 of SPE B, we predicted three domains most likely to be immunogenic (Figure 4a and b). Accordingly, a solid-phase peptide array containing 16 overlapped synthetic peptides from amino acids 266-350 (each containing 10 residues) was performed. We found that 
a

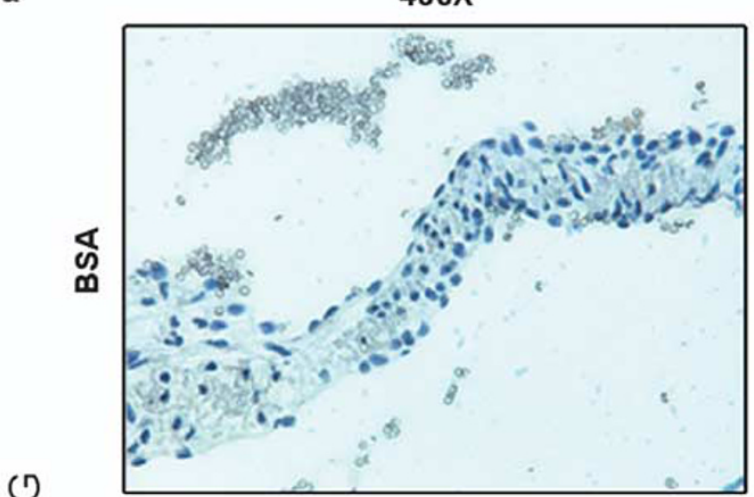

으

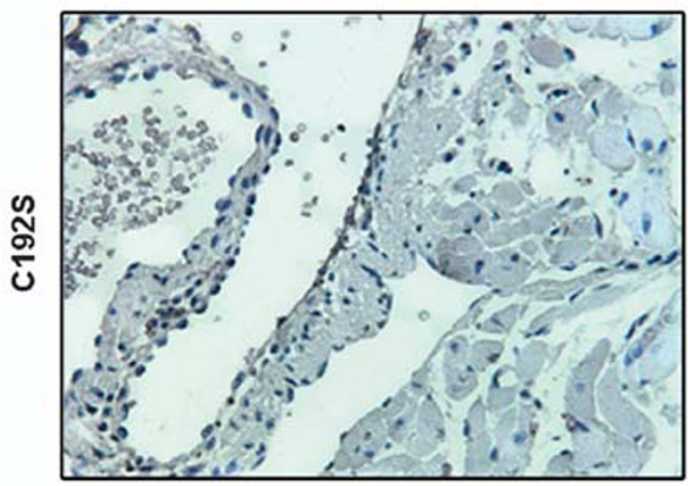

b

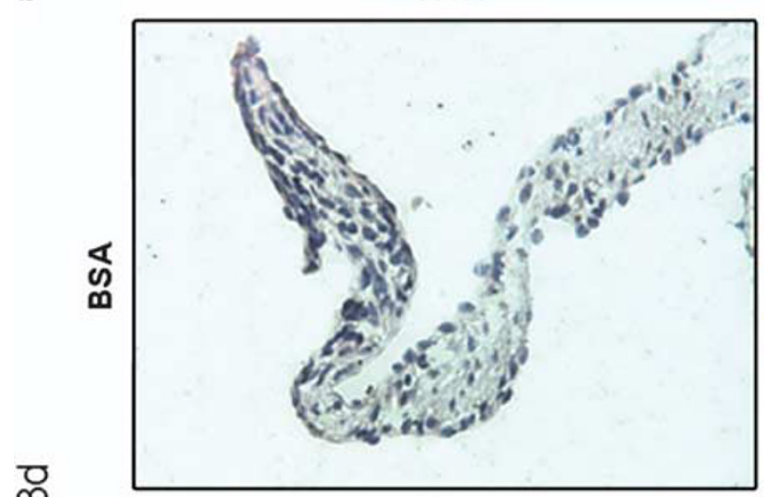

ก

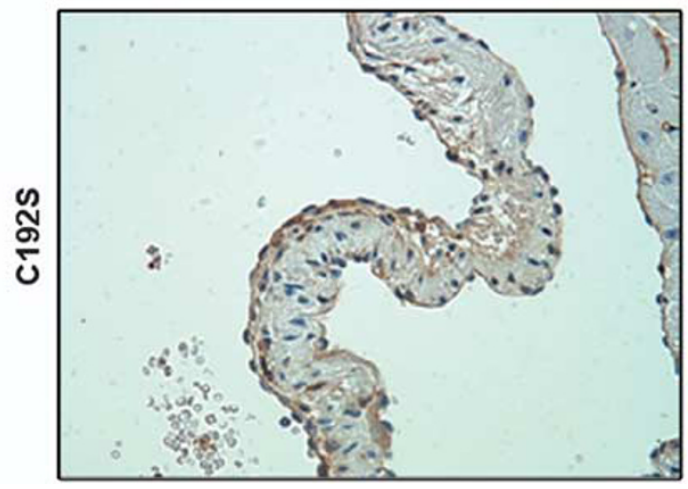

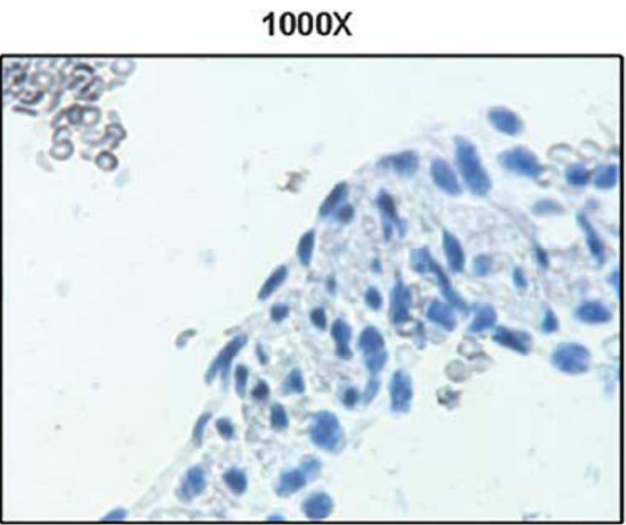

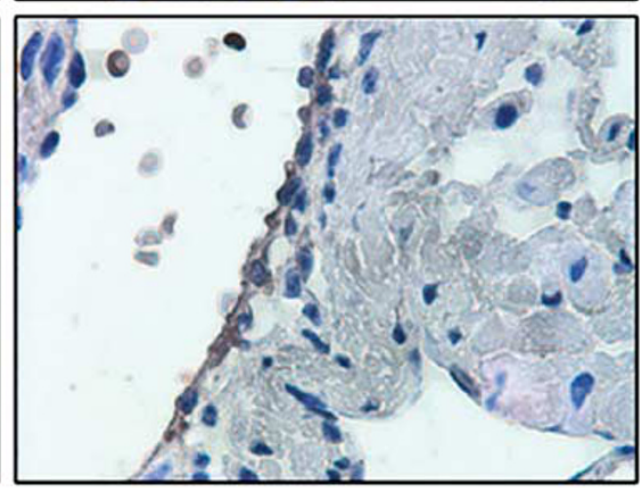

1000X
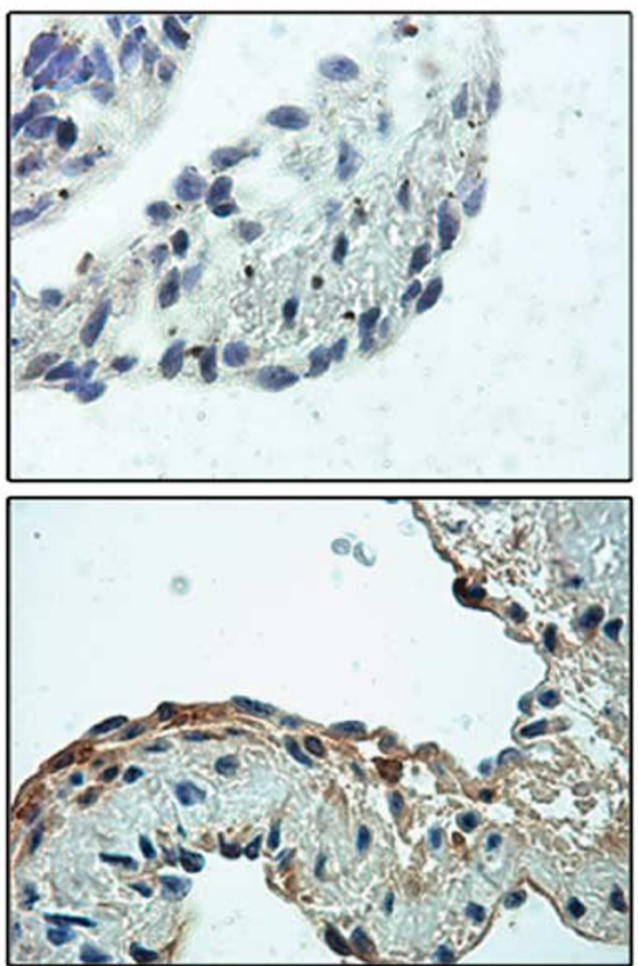

Figure 1 Immunoglobulin deposition, complement activation, and apoptosis in the heart valve of SPE B-immunized mice. BALB/c mice were immunized four times with BSA or with $28 \mathrm{kDa}$ SPE B mutant protein C192S $(n=5)$. (a) Immunoglobulin deposits were detected using HRP-conjugated anti-mouse IgG with light microscopy. (b) Complement C3 deposits were detected using anti-C3d antibody with light microscopy. (c) Using TUNEL assay, cell apoptosis was detected in the valve of SPE B-immunized mice. The visible light microscopy images correspond to the fields showing TUNEL staining (magnification $\times 400$ ). 

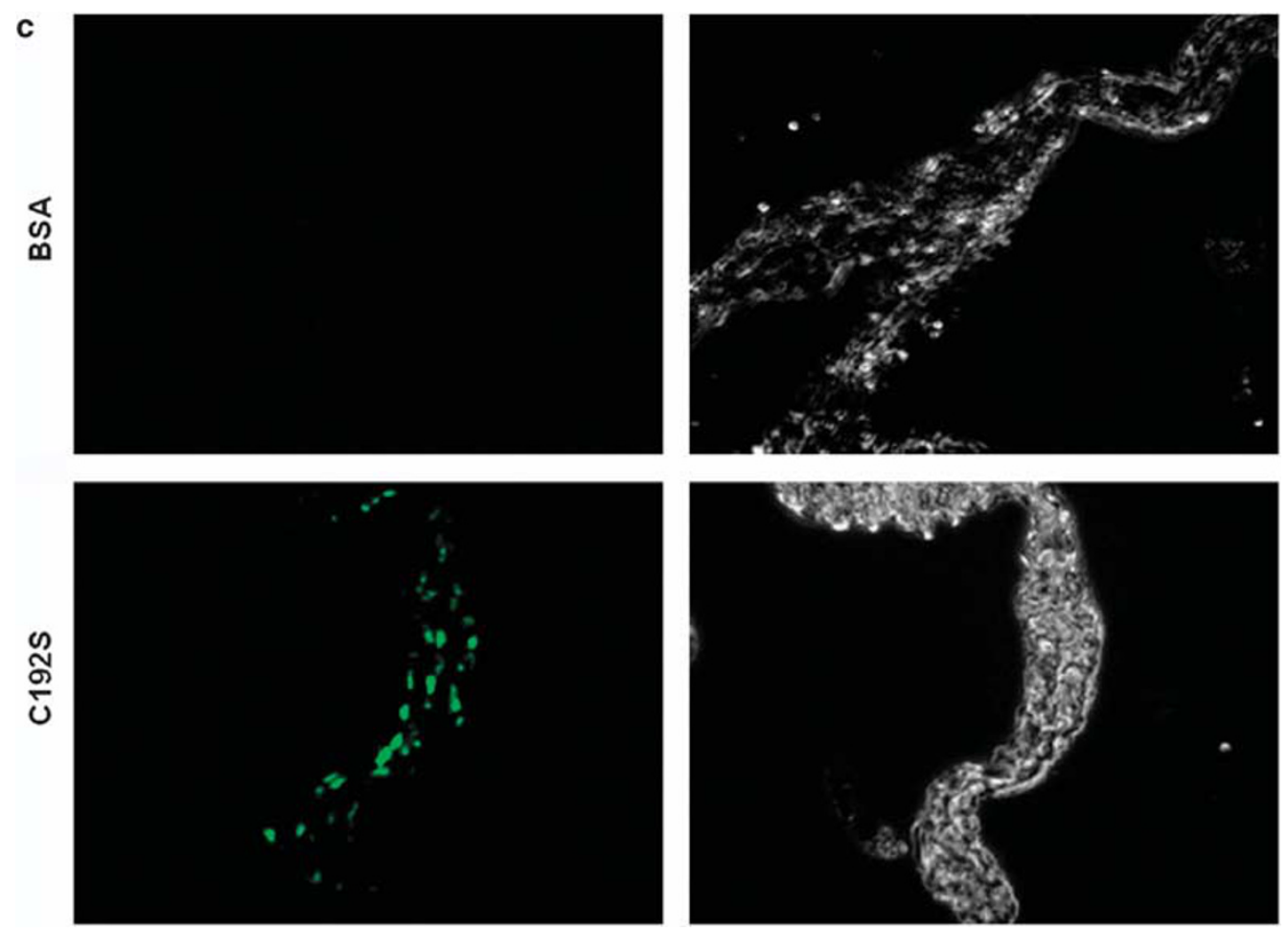

Figure 1 Continued.

mAb 10G predominantly bound to peptides 1 (amino acids 266-275), 4 (amino acids 281-290), 8 (amino acids 301-310), 10 (amino acids 311-320), 15 (amino acids 336-345), and 16 (amino acids 341-350) (Figure 4c). We then examined the dominant epitope recognized by $\mathrm{mAb}$ $10 \mathrm{G}$ using synthetic peptides. By ELISA, we found that amino acids 296-310 (P7-8) were recognized by mAb 10G, but not by $\mathrm{mAb} 9 \mathrm{C}$ (Figure $5 \mathrm{a}$ ). We used synthetic peptides for competition of mAb 10G binding. Using P7-8 peptides for competition, the binding activity of mAb $10 \mathrm{G}$ to C192S was reduced (Figure 5b). C192S was used as a positive control and SPEB-2 (amino acids 166-177) served as a negative control. Furthermore, we showed that the binding activity of mAb 10G to endothelial cells was inhibited by P7-8, but not other peptides (Figure $5 \mathrm{c}$ ).

We also used SPE B mutant proteins to study their interactions with $\mathrm{mAb} 10 \mathrm{G}$. The results showed that G281A, G308S, and V334A had lower reactivity to mAb 10G as compared with Q102N, C192S, and W357A (Figure 6). The amino-acid residue G308 is located within P7-8, whereas residues G281 and V334 are located on the surface loop and nearby but not in P7-8. These results suggested that the epitope recognized by $\mathrm{mAb} 10 \mathrm{G}$ is a conformational epitope.

\section{Reactivity of mAb $10 \mathrm{G}$ with GIcNAc}

Previous studies have shown that anti-streptococcal antibodies cross-react with cardiac myosin, tropomyosin, laminin, and vimentin. ${ }^{9}$ In addition, these cross-reactive antibodies recognize streptococcal $\mathrm{M}$ protein and carbohydrate
GlcNAc. We next tested the cross-reactivity of mAb $10 \mathrm{G}$ with GlcNAc-BSA and recombinant M1 protein (obtained from Dr Ching-Chuan Liu, Department of Pediatrics, National Cheng Kung University Hospital). The results showed that mAb 10G can bind to GlcNAc-BSA, but not BSA or M1 protein (Figure 7a). The P7-8 peptides and C192S were used as controls, showing the binding of $10 \mathrm{G}$ but not $9 \mathrm{C}$ to P7-8 and of both 9C and 10G to C192S. The doseresponse curves of $\mathrm{mAb} 10 \mathrm{G}$ reactive with GlcNAc-BSA, C192S, P7-8, and EMP, but not with BSA and SPE A, are shown (Figure $7 \mathrm{~b}$ ). The $\mathrm{mAb} 9 \mathrm{C}$ reacted only with C192S, but not other proteins tested. GlcNAc-BSA using molar ratios of 5:1, 10:1, and 50:1 all showed high cross-reactivity with $\mathrm{mAb}$ 10G, but not with mAb 9C (Figure 8a). The anti-GlcNAc-BSA sera and anti-P7-8 sera also possessed binding activity to GlcNAc, C192S, and P7-8 (Figure 8b). Competition assay showed that the reactivity of mAb $10 \mathrm{G}$ with GlcNAc-BSA (Figure 9a) and P7-8 peptides (Figure 9b) was inhibited by both GlcNAc-BSA and P7-8. Therefore, our results suggest that $\mathrm{mAb} 10 \mathrm{G}$ can also cross-react with GlcNAc. Furthermore, using immunohistochemical staining, we found that mAb 10G and anti-laminin colocalized on the mouse valve (Figure 10).

\section{DISCUSSION}

The association of anti-cardiac antibodies with acute rheumatic fever is well documented. ${ }^{43-46}$ Prolonged persistence of streptococcal group A antibody is a characteristic in patients with rheumatic valvular disease. ${ }^{47}$ Antibody and complement are found deposited in the heart of RHD patients. ${ }^{43}$ 
a

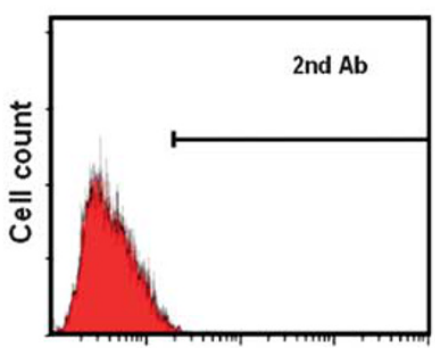

Relative fluorescence

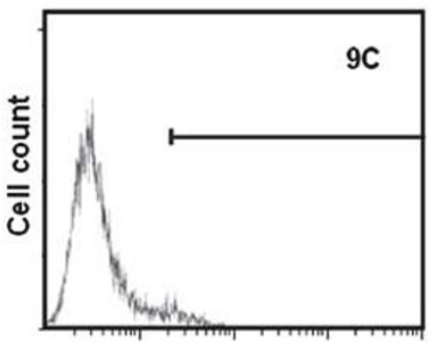

Relative fluores cence

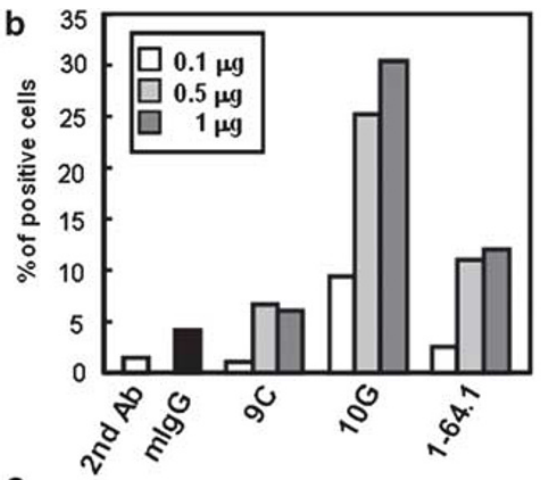

C

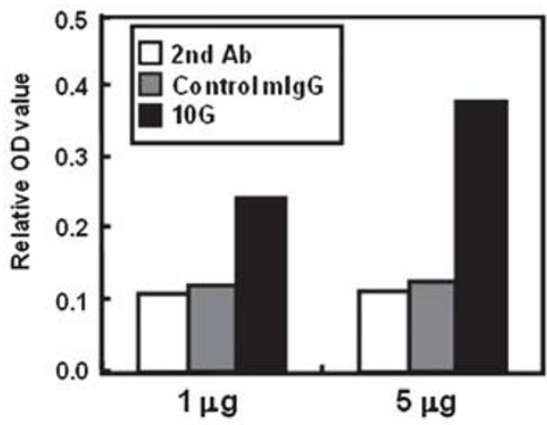

Endothelial membrane proteins d
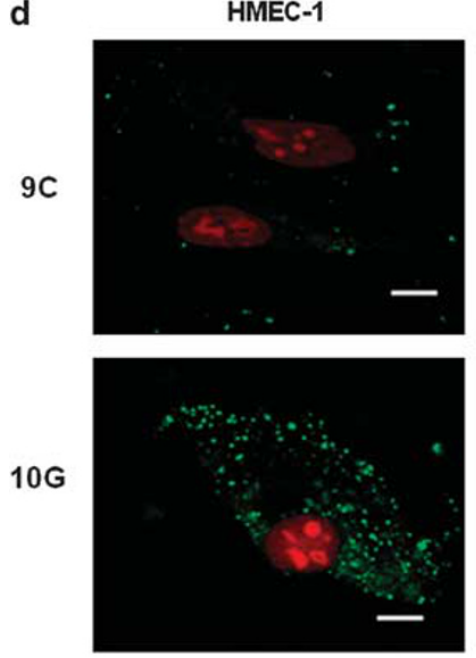

$8 \overline{8 m}$ e
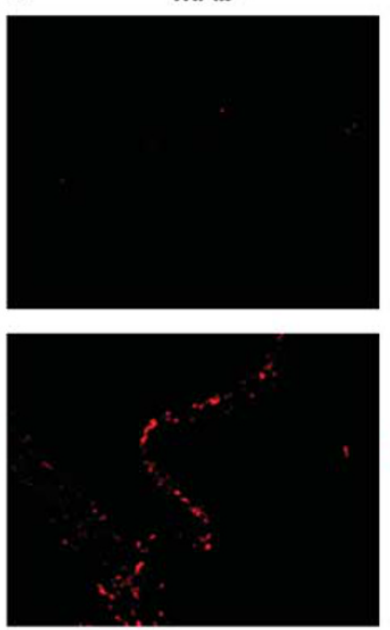

$1-64.1$ 
a

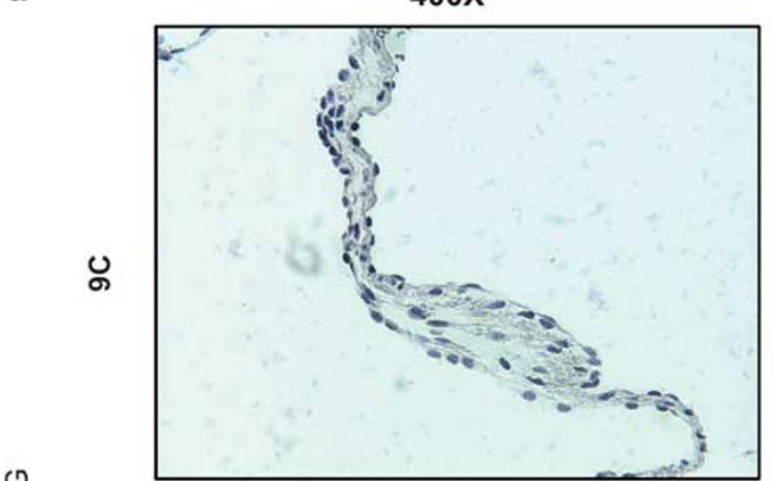

밈

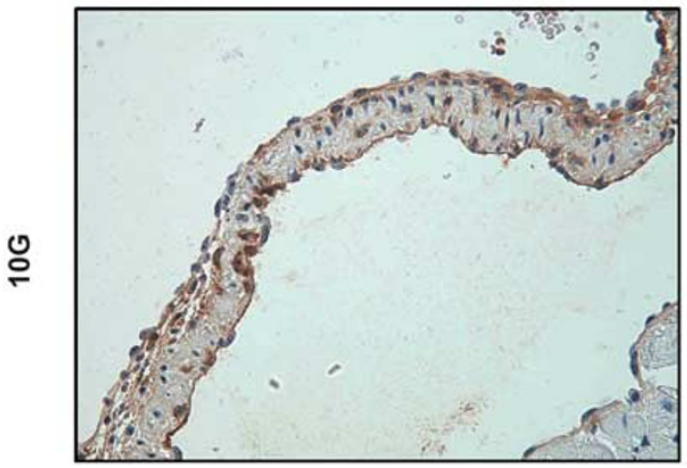

b

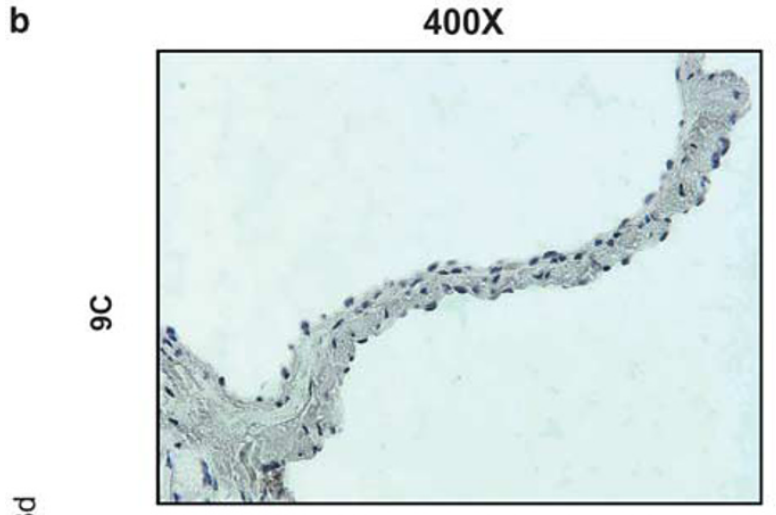

ర్ల

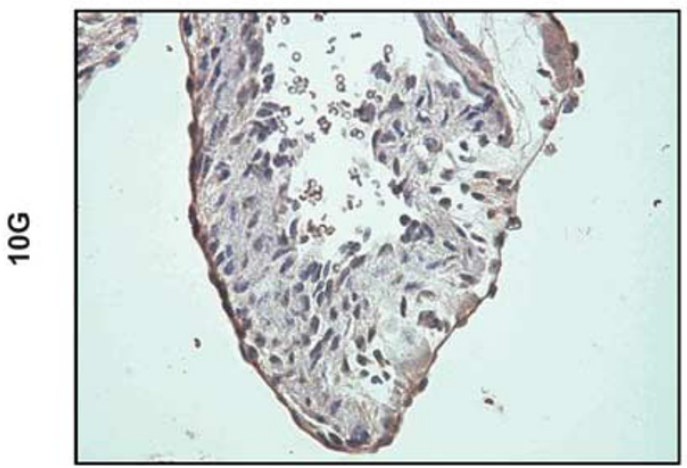

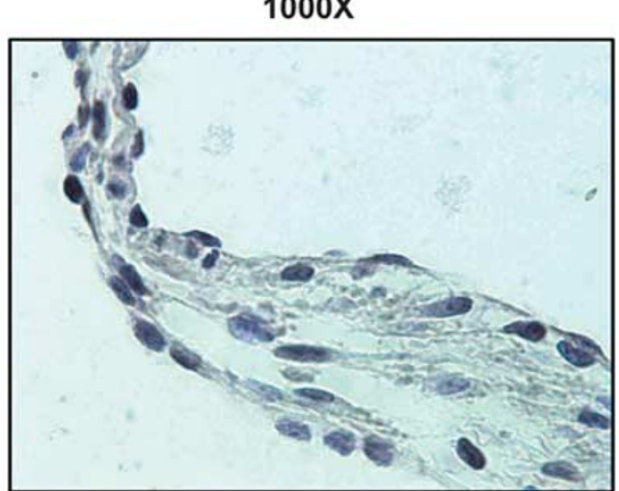

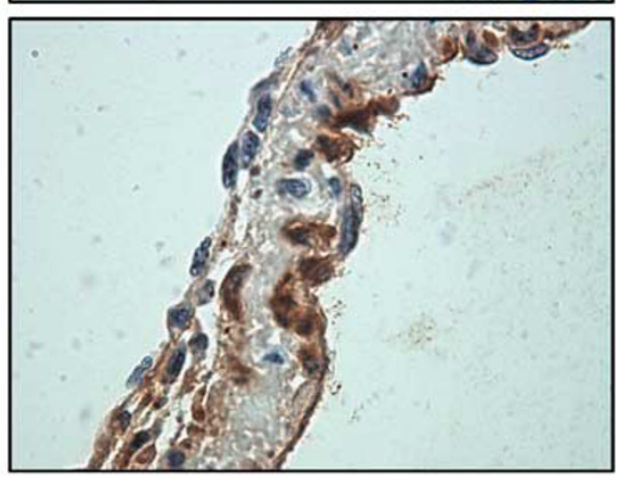

$1000 x$
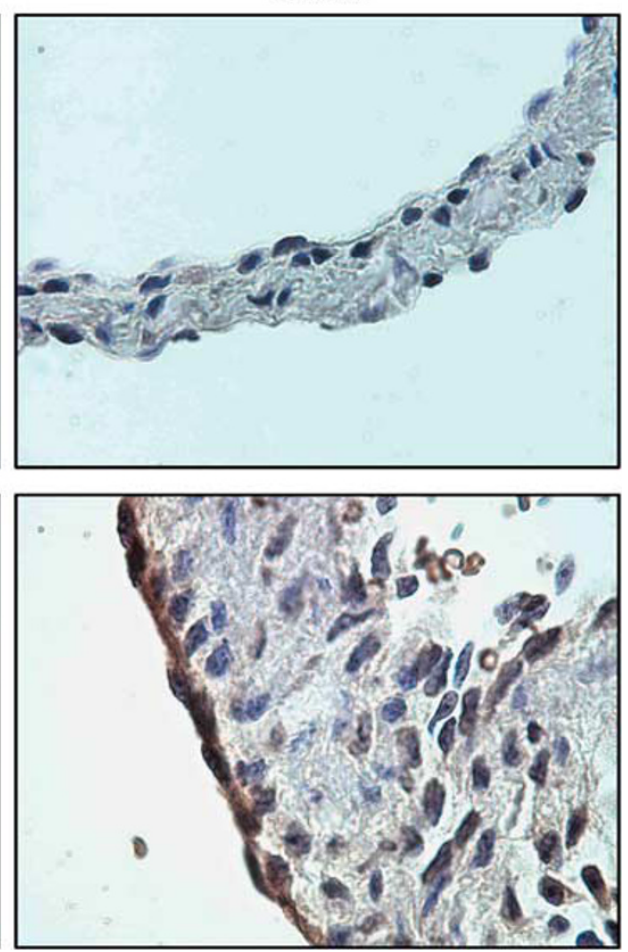

Figure 3 Immunoglobulin deposition, complement activation, and apoptosis in the heart valve of mice after passive immunization with mAb 10G. BALB/c mice were intravenously immunized each day with $500 \mu \mathrm{g}$ of $9 \mathrm{C}$ or $\mathrm{mAb} 10 \mathrm{G}$ for 3 days and, after 7 days, the heart sections were analyzed using HRPconjugated anti-mouse IgG (a) and anti-C3d antibody (b), and TUNEL assay (c) ( $n=3$ per group). The visible light microscopy images correspond to the fields showing TUNEL staining (magnification $\times 400$ ). 

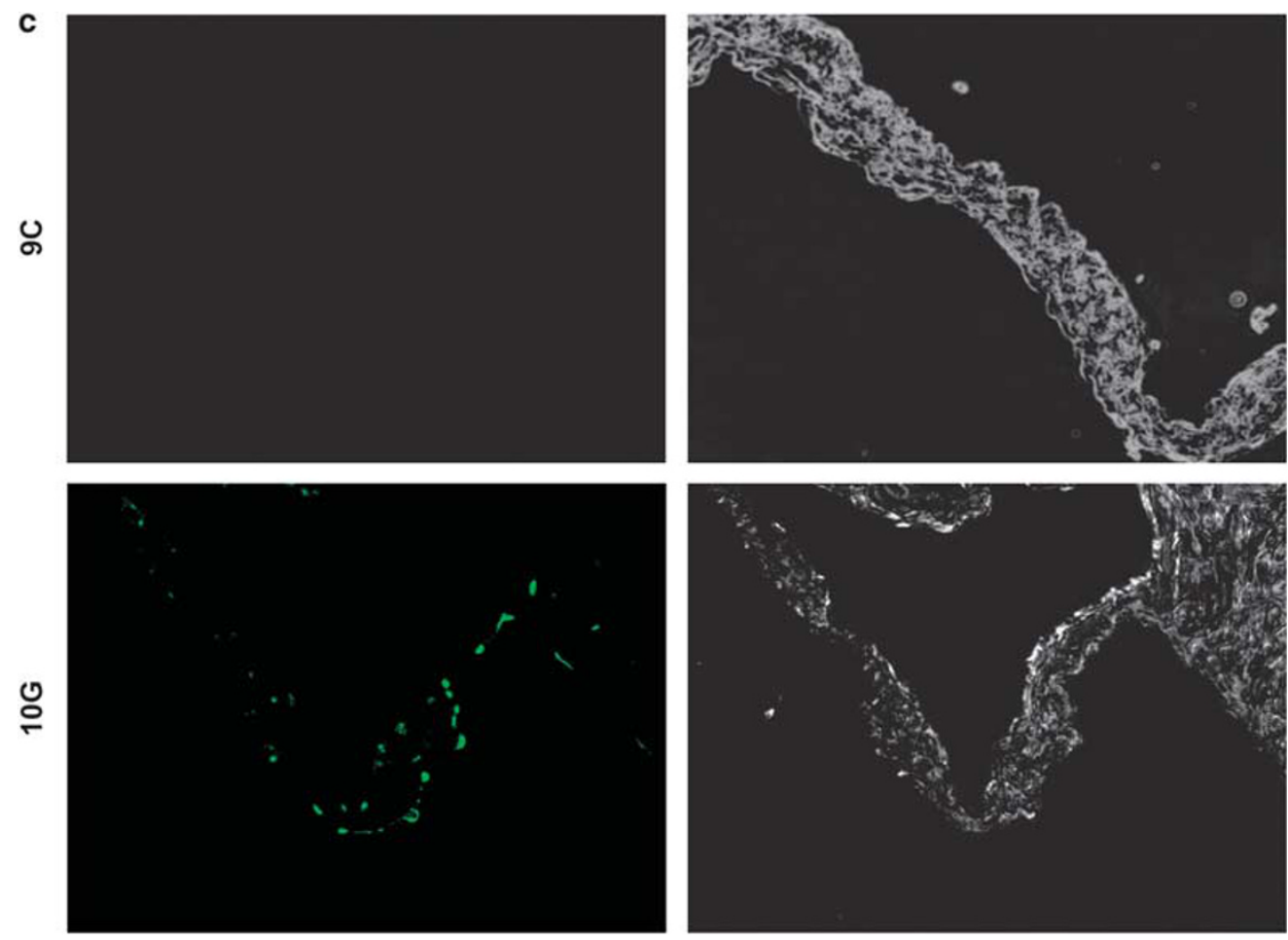

Figure 3 Continued.
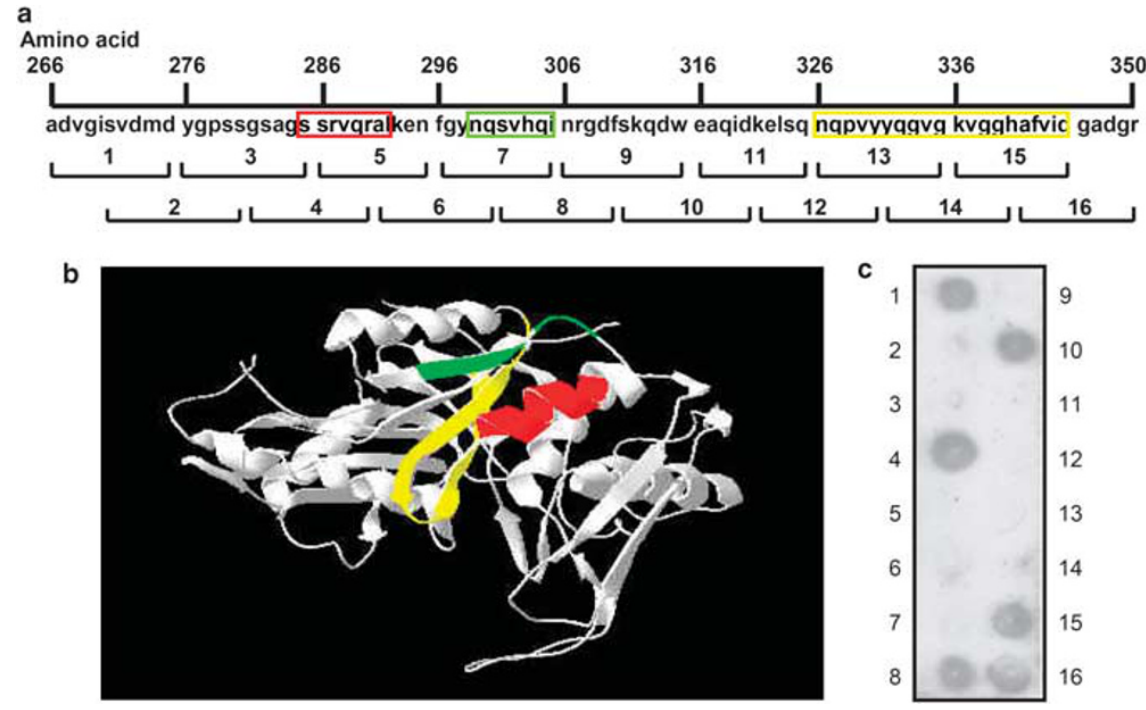

Figure 4 Delineation of the SPE B antigenic epitope recognized by mAb 10G. An EMBOSS program was used to search for potential antigenic determinants within residues 266-350 of SPE B. The red, green, and yellow squares indicate potential epitopes (a), which are marked in the three-dimensional structure of SPE B (b). (c) For peptide array, 16 peptides corresponding to SPE B residues 266-350, as indicated in panel a, were directly synthesized in situ on nitrocellulose membrane. Binding of MAb $10 \mathrm{G}$ was performed, followed by HRP-conjugated anti-mouse IgG with chemiluminescent agent as a developer.

recruitment through the activated endothelium into the valve. $^{23}$ Therefore, the binding of cross-reactive antibodies to the endothelium causes endothelial activation at the initiating stage. ${ }^{9}$ Laminin or other cross-reactive proteins contribute to the deposition of antibodies on the valve. Cross-reactive antibodies may bind directly to the valve endothelium or may bind to the basement membrane of the valve, which lead to inflammatory activation in the endothelium. ${ }^{24}$ In this study, we showed an anti-SPE B mAb $10 \mathrm{G}$ which can cross-react with endothelial cells and result in inflammatory activation on the valve. Interestingly, mAb 10G can also cross-react with the carbohydrate epitope GlcNAc. 

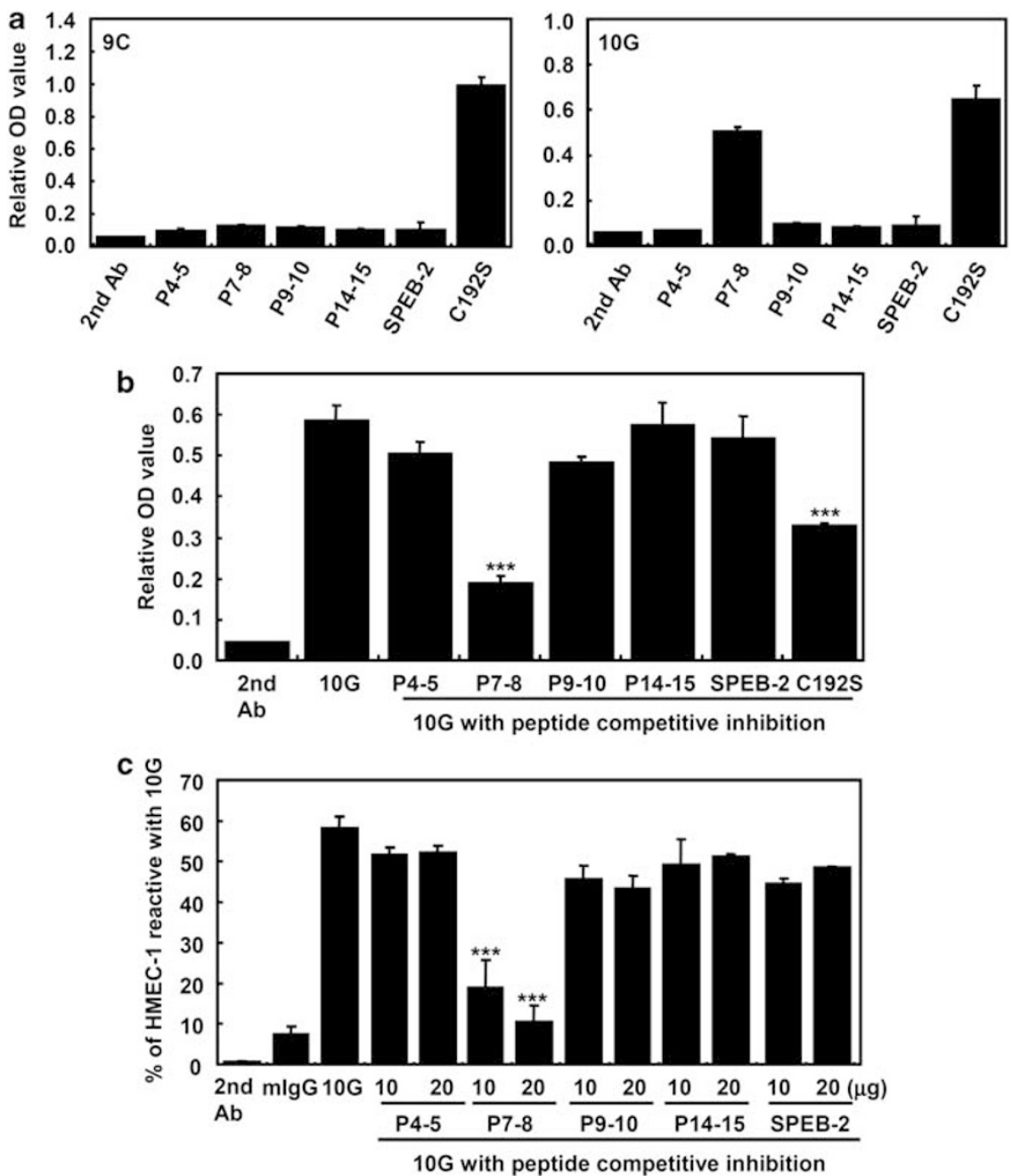

Figure 5 The SPE B- and endothelial cell-binding activities of mAb 10G are inhibited using P7-8 for competition. (a) The synthetic peptides (100 $\mu$ l per well of $10 \mu \mathrm{g} / \mathrm{ml}$ ) were coated in the ELISA plate. $\mathrm{mAb} 9 \mathrm{C}$ or $10 \mathrm{G}(1 \mu \mathrm{g})$ was then added, followed by HRP-conjugated anti-mouse lgG. The binding activities are shown as mean \pm s.d. of triplicate cultures. SPEB-2 was used as a negative control peptide, and C192S was a positive control. (b) $\mathrm{mAb} 10 \mathrm{G}$ (1 $\mu \mathrm{g})$ was preincubated with $5 \mu \mathrm{g}$ of synthetic peptides at room temperature for $1.5 \mathrm{~h}$, and the large complex was removed by centrifugation at $13000 \mathrm{~g}$ for $15 \mathrm{~min}$. Their binding activities to C192S were then determined by ELISA. Data are shown as mean \pm s.d. of triplicate cultures. (c) $\mathrm{mAb} 10 \mathrm{G}(1 \mu \mathrm{g})$ was preincubated with 10 or $20 \mu \mathrm{g}$ of synthetic peptides. Their binding activities to HMEC-1 cells were then analyzed by flow cytometry. The percentages of HMEC-1 cells reactive with $\mathrm{mAb} 10 \mathrm{G}$ with or without peptide preincubation are shown as mean \pm s.d. of triplicate cultures. SPEB-2 was used as a negative control peptide. ${ }^{* * *} P<0.001$ as compared with the group without peptide preincubation.

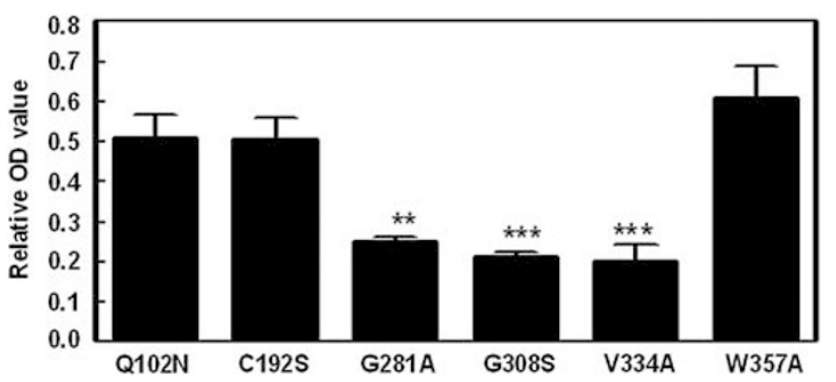

Figure 6 Binding ability of $\mathrm{mAb} 10 \mathrm{G}$ with different SPE B mutant proteins. SPE B mutant proteins $(100 \mu \mathrm{l}$ per well of $10 \mu \mathrm{g} / \mathrm{ml})$ were coated in ELISA plate. mAb 10G $(1 \mu \mathrm{g})$ was added, followed by HRP-conjugated anti-mouse IgG. The binding activities are shown as mean \pm s.d. of triplicate cultures. ${ }^{* *} P<0.01,{ }^{* * *} P<0.001$ as compared with $10 \mathrm{G}$ binding activity to C192S.
Our previous study has shown that anti-SPE B antibodies bound to glomerular endothelial cells and caused immune complex deposition, leading to renal injury. ${ }^{35}$ There are at least two forms of antibody-associated kidney injury. One is caused by antibodies reacting with glomerular antigens, and the other is caused by deposits of immune complexes. We have previously shown that anti-SPE B antibodies cause kidney damage by molecular mimicry to glomerular endothelial cell antigens. In this study, we found IgG deposition, complement activation, and cell apoptosis in the valve by either active immunization with SPE B or passive immunization with anti-SPE B mAb 10G. Our results suggested that the deposition of anti-SPE $\mathrm{B}$ antibodies crossreact with heart endothelial cells, leading to inflammatory 


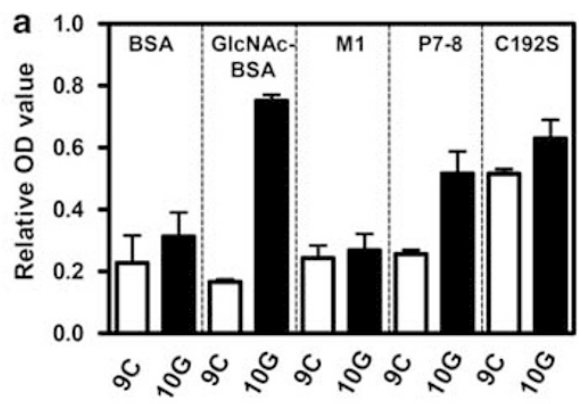

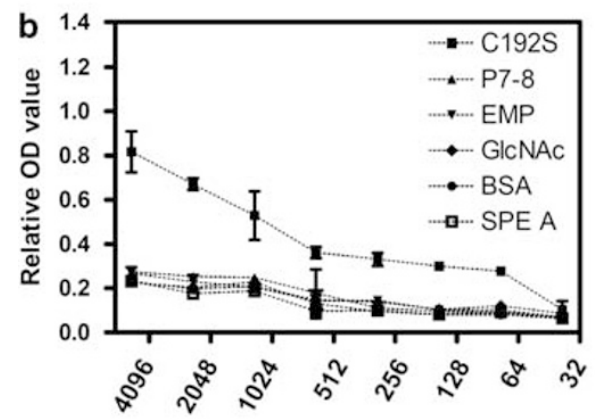

Concentration of $\mathrm{mAb} 9 \mathrm{C}(\mathrm{ng} / \mathrm{ml})$

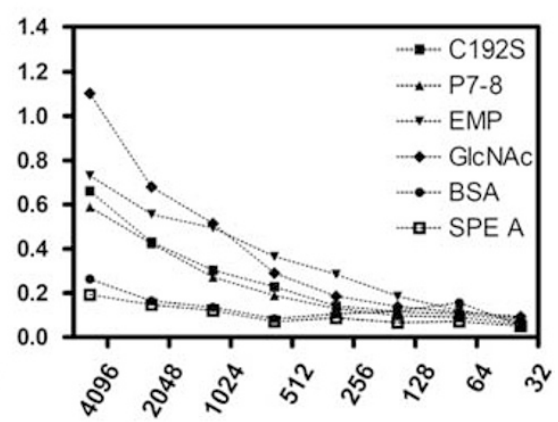

Concentration of $\mathrm{mAb} 10 \mathrm{G}(\mathrm{ng} / \mathrm{ml})$

Figure $7 \mathrm{mAb} 10 \mathrm{G}$ binds to GlcNAc but not M1 protein. (a) BSA, GlcNAc-BSA, M1, P7-8 peptides, and C192S (100 $\mu \mathrm{l}$ per well of $10 \mu \mathrm{g} / \mathrm{ml})$ were coated in ELISA plate. $\mathrm{mAb} 9 \mathrm{C}$ or $10 \mathrm{G}(1 \mu \mathrm{g})$ was added, followed by HRP-conjugated anti-mouse lgG. The binding activities are shown as mean $\pm \mathrm{s}$.d. of triplicate cultures. (b) Dose-response curves of mAb $9 \mathrm{C}$ and $10 \mathrm{G}$ binding to C192S, P7-8, EMP, GIcNAc-BSA, BSA, and SPE A using ELISA. The relative OD values are shown as the mean of triplicate cultures.
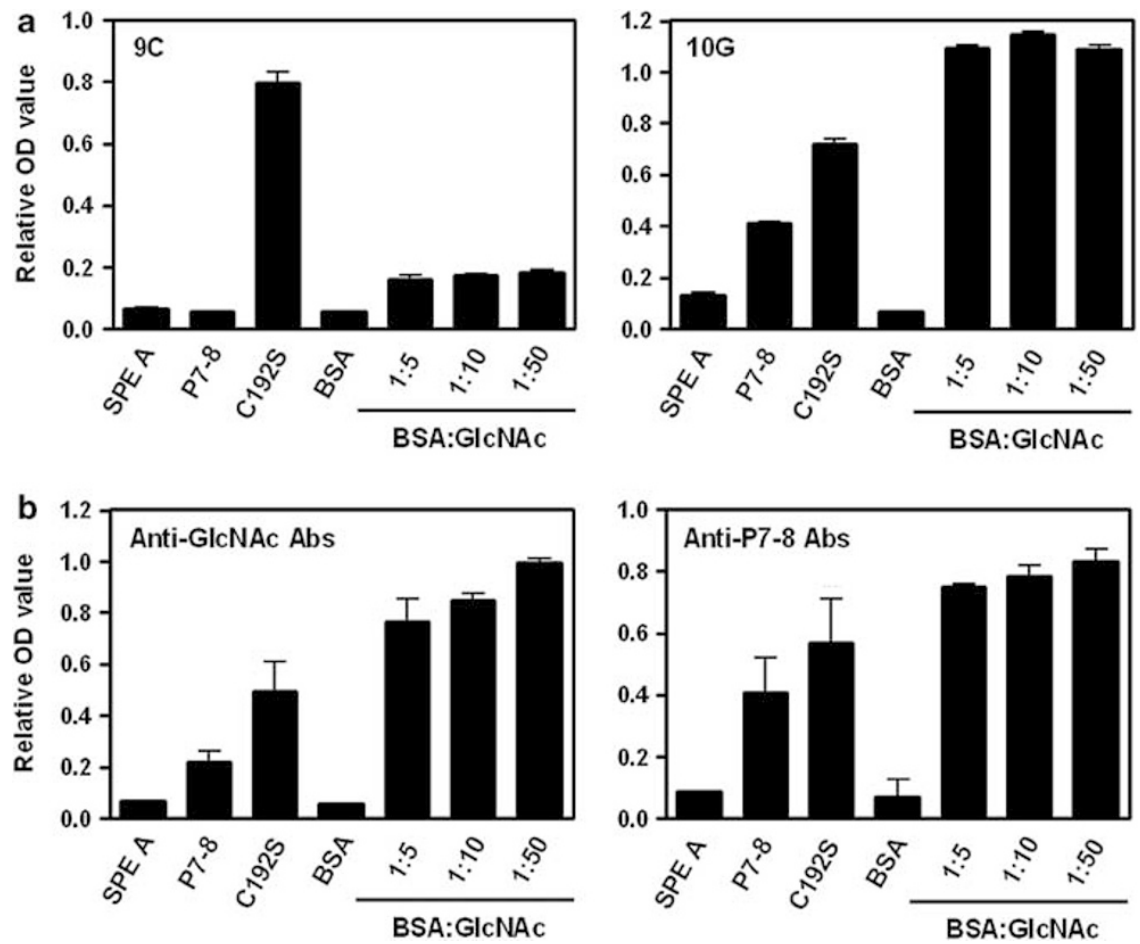

Figure 8 Binding activities of $m A b 9 C, 10 G$, anti-GIcNAc-BSA sera, and anti-P7-8 sera with GlcNAc-BSA conjugates containing variable GlcNAc:BSA ratios. SPE A, P7-8, C192S, BSA, and GlcNAc-BSA (100 $\mu \mathrm{l}$ per well of $10 \mu \mathrm{g} / \mathrm{ml})$ were coated onto an ELISA plate. mAb 9C, 10G (1 $\mu \mathrm{g})(\mathbf{a})$, anti-GlcNAc-BSA sera and anti-P7-8 sera (b) were added, followed by HRP-conjugated anti-mouse lgG. The binding activities are shown as mean \pm s.d. of triplicate cultures. 


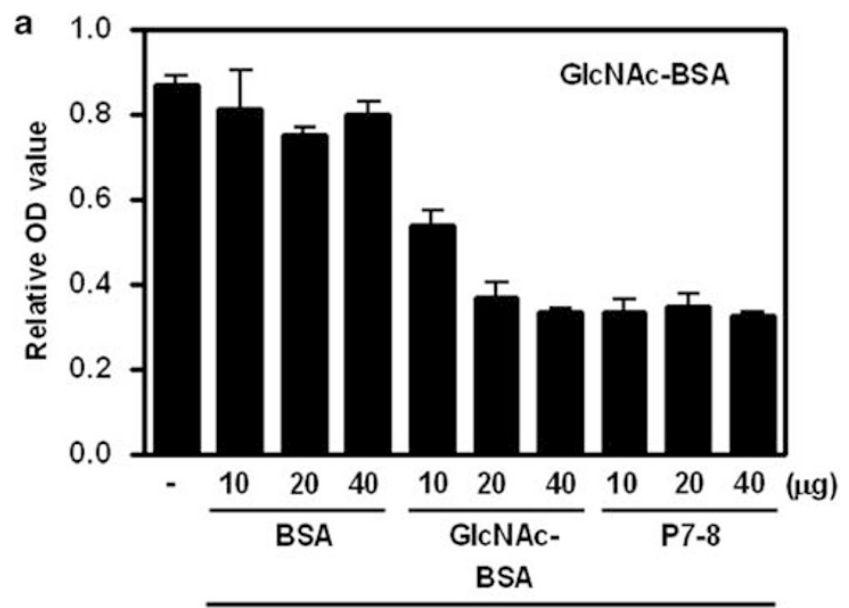

Competitive inhibition

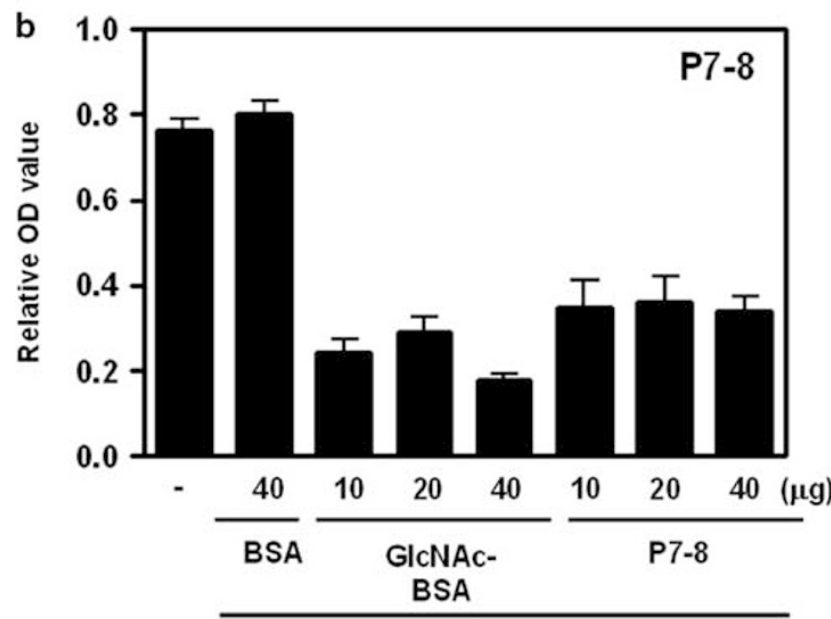

Competitive inhibition

Figure 9 The GlcNAc- and P7-8-binding activities of $\mathrm{mAb}$ 10G are inhibited using GlcNAc-BSA and P7-8 for competition. mAb 10G ( $1 \mu \mathrm{g})$ was pretreated with 10,20 , or $40 \mu \mathrm{g}$ of BSA, GICNAc-BSA, or P7-8 at room temperature for $1.5 \mathrm{~h}$ and large aggregates were removed by centrifugation. The supernatants were collected and their binding activities to GICNAC-BSA (a) and P7-8 peptides (b) were determined by ELISA. The binding activities are shown as mean \pm s.d. of triplicate cultures.

activation and cell death. The complement levels were reduced in RHD patient sera, suggesting that a complementmediated injury may have occurred in the course of the disease. ${ }^{53}$ It was reported that antibodies cross-reactive with the valvular tissue are present in rheumatic carditis patients, and that the valve may serve as a source of antigen to maintain the presence of autoantibodies. ${ }^{54}$ Such autoantibodies are cytotoxic to the human valvular endothelium and react with laminin in the basement membrane in vitro. ${ }^{55}$ Inflammatory signals from these antibodies and other immune mediators influence the expression of adhesion molecules on the valvular endothelium, which is a site for lymphocyte extravasation into the valve. The inflamed endocardium then attracts activated $\mathrm{T}$ cells and promotes a Th1 cytokine profile, leading to eventual scarring and heart murmur characteristic of rheumatic carditis. ${ }^{56}$

To determine the SPE B epitope recognized by anti-SPE B mAb 10G, our results showed that amino acids 296-310 (P7-8) possess the major epitope. In the peptide array, spot 8 , but not spot 7 , showed a positive reaction, possibly because of a conformational specificity of antibody binding. Although mAb $10 \mathrm{G}$ also reacted with peptides other than spot 8 , SPE B structural analysis and further confirmation assays excluded them as the dominant epitope for $\mathrm{mAb} 10 \mathrm{G}$ and endothelial cell binding. Only P7-8, but not other peptides, could inhibit SPE B- and endothelial cell-binding activity of mAb 10G. In addition, the endothelial cell-binding activity was only affected by removing antibodies against P7-8, whereas similar procedures for other peptides did not cause any effect. To validate the conformational specificity of antibody binding to P7-8, we constructed several sitedirected mutant proteins and found that G281A, G308S, and V334A mutants had lower binding ability with $\mathrm{mAb} 10 \mathrm{G}$ as compared with that of C192S mutant. In contrast, Q102N and W357A mutants showed similar binding activity with $\mathrm{mAb} 10 \mathrm{G}$ as that of C192S mutant. This is consistent with the prediction that the amino-acid residues G281, G308, and V334 are within EMBOSS-predicted antigenic epitopes, which are located in the region between residues 266 and 350. The residues G281 and V334 are located near the active site of SPE B, whereas the residue G308 is within a RGD motif which binds to integrins $\alpha_{\mathrm{v}} \beta_{3}$ and $\alpha_{\mathrm{IIb}} \beta_{3}$. These three residues are all located on the surface loops, and their spatial positions are close to each other. Although the major epitope is located within amino-acid residues 296-310 (P7-8), the alteration of amino-acid residues 281 or 334 would reduce the mAb 10G binding ability. Therefore, these findings suggest that $\mathrm{mAb}$ $10 \mathrm{G}$ recognizes a conformational epitope.

A previous report showed that a $\mathrm{mAb}$ cross-reactive with group A streptococcal M protein recognizes GlcNAc. ${ }^{39}$ Using binding and competition assays, we also found that $\mathrm{mAb} 10 \mathrm{G}$ can recognize GlcNAc. This finding implies a conformational similarity between P7-8 and GlcNAc. mAb 10G does not bind to M1 protein. The possibility that $\mathrm{mAb} 10 \mathrm{G}$ can bind to other $\mathrm{M}$ proteins remains to be determined. Pronounced immunological cross-reactivity has been previously reported between the GAS polysaccharide and structural glycoproteins isolated from the heart valves. ${ }^{57}$ In addition, previous studies on mAbs that recognize GlcNAc residues of GAS carbohydrate, a cell-wall polysaccharide composed of a polyrhamnose backbone and $\beta$-1,3-linked GlcNAc side chains, showed that these mAbs also reacted with O-GlcNAcbearing glycoproteins. ${ }^{58}$ Whether the O-linked GlcNAc glycoproteins present on valve endothelial cells is recognized by mAb $10 \mathrm{G}$ remains to be investigated.

We previously showed that the heat-shock protein 70 (HSP70) present in the HMEC-1 cell membrane extract was recognized by mAb 10G. ${ }^{35}$ Although $\mathrm{mAb} 10 \mathrm{G}$ binds to mouse valve endothelial cells, we could not detect the binding 

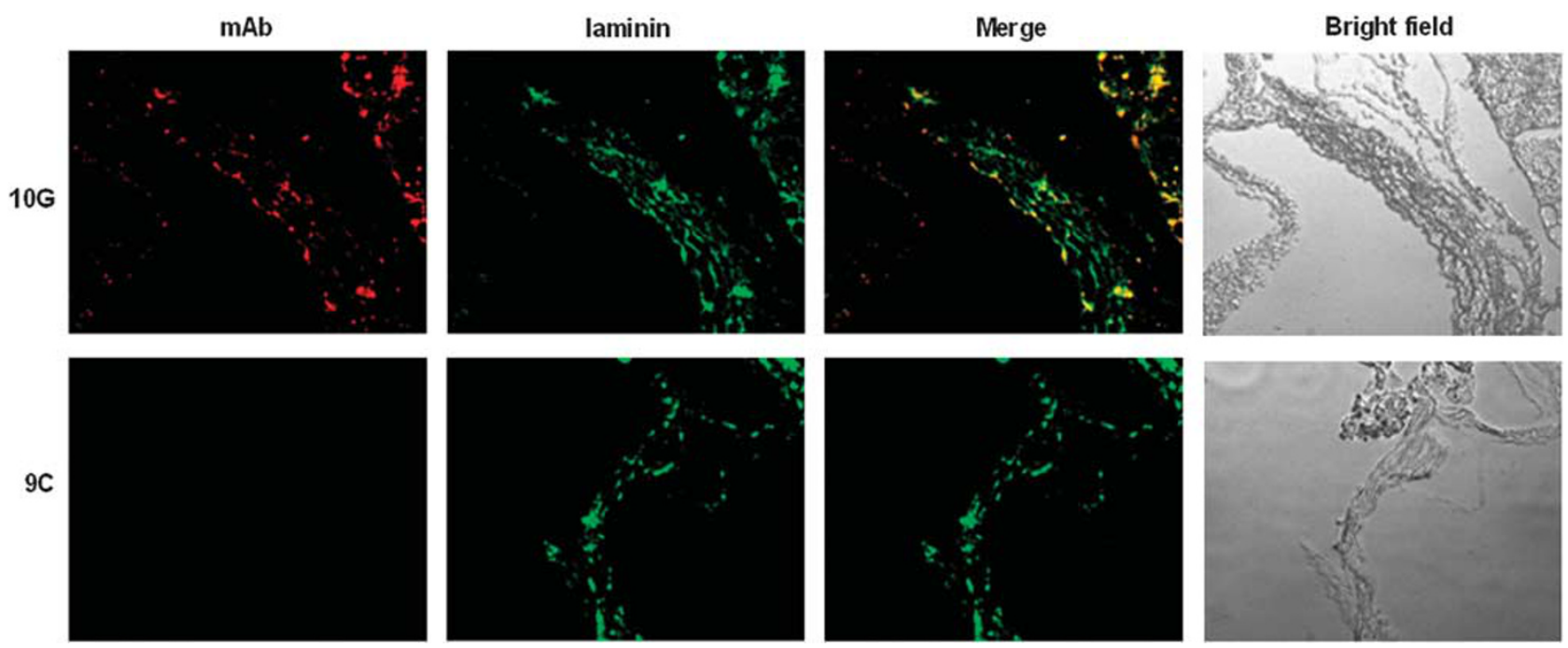

Figure 10 Colocalization of $\mathrm{mAb} 10 \mathrm{G}$ with laminin on mouse valve. Mouse heart tissue sections were first stained with $\mathrm{mAb} 9 \mathrm{C}$ or $10 \mathrm{G}$ (red) and then with anti-laminin antibodies (green). Their colocalization on the valve is shown (merge, yellow) (magnification $\times 400$ ).

of anti-HSP70 antibodies to these cells (data not shown). We speculate that, unlike HMEC-1 cells, the surface expression level of HSP70 on mouse valve endothelial cells may be too low to be detected. Nevertheless, HSP70 has been previously reported to be found at the cell surface and may contribute to the development of cardiovascular and autoimmune diseases. ${ }^{59}$ In addition, RHD patient sera have been reported to recognize myocardial antigen, which was identified as constitutive HSP70 (HSP73). ${ }^{60}$ Whether the recognition of HSP70 by anti-SPE B antibodies is involved in the disease pathogenesis needs further investigation. It has also been previously reported that human anti-streptococcal carbohydrate mAb3B6 from rheumatic carditis reacted with valve endothelial cell laminin. ${ }^{55}$ Immunohistochemical staining results showed that mAb $10 \mathrm{G}$ and anti-laminin colocalized on the valve, suggesting that $10 \mathrm{G}$ may cross-react with valve endothelial cells by molecular mimicry with laminin. This hypothesis needs to be further confirmed.

M-protein-based subunit vaccine development is currently in progress. However, the diversity of $\mathrm{M}$ protein types and the possibility of inducing autoimmunity after vaccination raise concerns for vaccine development. ${ }^{61}$ Different M-protein-based vaccine approaches have been aimed at the development of safe and broad protective immunity. ${ }^{62} \mathrm{We}$ previously showed that both active and passive SPE B immunization of mice conferred protection from GAS challenge. ${ }^{63}$ Deletion or mutation of the cross-reactive epitopes to avert autoimmune complications might provide a strategy against GAS infection. Although the presence of other crossreactive epitopes cannot be excluded, our study indicated that a dominant epitope is located within amino-acid residues $296-310$.

In conclusion, we have shown that anti-SPE B antibodies can cross-react with endothelial cells. Immunoglobulin deposition, complement activation, and cell apoptosis were observed in the heart valve of SPE B-immunized and mAb 10G passively immunized mice. We have identified a dominant epitope which is located within amino-acid residues 296-310 of SPE B. The colocalization results suggest that mAb 10G might cross-react with laminin and GlcNAc. The antigenic similarity between these protein and carbohydrate epitopes recognized by $\mathrm{mAb} 10 \mathrm{G}$ requires further investigation.

Supplementary Information accompanies the paper on the Laboratory Investigation website (http://www.laboratoryinvestigation.org)

\section{ACKNOWLEDGEMENT}

We thank Dr Robert Anderson for critical reading of this paper. We also thank Dr Chun-I Sze for helpful advice on histopathology. This work was supported by grant NHRI-EX95-9429SP from the National Health Research Institutes, Taiwan.

\section{DISCLOSURE/CONFLICT OF INTEREST}

The authors declare no conflict of interest.

1. Bisno AL, Brito MO, Collins CM. Molecular basis of group A streptococcal virulence. Lancet Infect Dis 2003;3:191-200.

2. Carapetis JR, Steer AC, Mulholland EK, et al. The global burden of group A streptococcal diseases. Lancet Infect Dis 2005;5:685-694.

3. Carapetis JR, McDonald M, Wilson NJ. Acute rheumatic fever. Lancet 2005;366:155-168.

4. Cunningham MW. Pathogenesis of group A streptococcal infections. Clin Microbiol Rev 2000;13:470-511.

5. Graham MR, Smoot LM, Lei B, et al. Toward a genome-scale understanding of group A streptococcus pathogenesis. Curr Opin Microbiol 2001;4:65-70.

6. Currie BJ. Group A streptococcal infections of the skin: molecular advances but limited therapeutic progress. Curr Opin Infect Dis 2006;19:132-138.

7. McDonald M, Currie BJ, Carapetis JR. Acute rheumatic fever: a chink in the chain that links the heart to the throat? Lancet Infect Dis 2004;4:240-245.

8. Tart AH, Walker MJ, Musser JM. New understanding of the group A streptococcus pathogenesis cycle. Trends Microbiol 2007;15: 318-325. 
9. Guilherme L, Kalil J, Cunningham M. Molecular mimicry in the autoimmune pathogenesis of rheumatic heart disease. Autoimmunity 2006;39:31-39.

10. Kirvan CA, Swedo SE, Heuser JS, et al. Mimicry and autoantibodymediated neuronal cell signaling in Sydenham chorea. Nat Med 2003;9:914-920.

11. Martins TB, Veasy LG, Hill HR. Antibody responses to group A streptococcal infections in acute rheumatic fever. Pediatr Infect Dis $J$ 2006;25:832-837.

12. Carapetis JR. Rheumatic heart disease in developing countries. N Engl J Med 2007;357:439-441.

13. Marijon E, Ou P, Celermajer DS, et al. Prevalence of rheumatic heart disease detected by echocardiographic screening. $\mathrm{N}$ Engl J Med 2007;357:470-476.

14. Guilherme L, Cury P, Demarchi LM, et al. Rheumatic heart disease: proinflammatory cytokines play a role in the progression and maintenance of valvular lesions. Am J Pathol 2004;165:1583-1591.

15. Kudat $H$, Telci $G$, Sozen $A B$, et al. The role of HLA molecules in susceptibility to chronic rheumatic heart disease. Int J Immunogenet 2006;33:41-44.

16. Kurahara D, Tokuda A, Grandinetti A, et al. Ethnic differences in risk for pediatric rheumatic illness in a culturally diverse population. J Rheumatol 2002;29:379-383.

17. Ramasawmy R, Fae KC, Spina G, et al. Association of polymorphisms within the promoter region of the tumor necrosis factor- $\alpha$ with clinica outcomes of rheumatic fever. Mol Immunol 2007:44:1873-1878.

18. Cunningham MW, Antone SM, Smart M, et al. Molecular analysis of human cardiac myosin-cross-reactive $B$ - and T-cell epitopes of the group A streptococcal M5 protein. Infect Immun 1997;65:3913-3923.

19. Cunningham MW. T cell mimicry in inflammatory heart disease. Mol Immunol 2004;40:1121-1127.

20. Ellis NMJ, Li Y, Hildebrand W, et al. T cell mimicry and epitope specificity of cross-reactive $T$ cell clones from rheumatic heart disease. J Immunol 2005;175:5448-5456.

21. Fae KC, da Silva DD, Oshiro SE, et al. Mimicry in recognition of cardiac myosin peptides by heart-intralesional $\mathrm{T}$ cell clones from rheumatic heart disease. J Immunol 2006;176:5662-5670.

22. Guilherme L, Fae K, Oshiro SE, et al. Molecular pathogenesis of rheumatic fever and rheumatic heart disease. Expert Rev Mol Med 2005;7:1-15.

23. Roberts S, Kosanke S, Dunn ST, et al. Pathogenic mechanisms in rheumatic carditis: focus on valvular endothelium. J Infect Dis 2001;183:507-511.

24. Cunningham MW. Autoimmunity and molecular mimicry in the pathogenesis of post-streptococcal heart disease. Front Biosci 2003:8:s533-s543.

25. Fenderson PG, Fischetti VA, Cunningham MW. Tropomyosin shares immunologic epitopes with group A streptococcal M proteins. J Immunol 1989;142:2475-2481.

26. Gulizia JM, Cunningham MW, McManus BM. Immunoreactivity of antistreptococcal monoclonal antibodies to human heart valves. Evidence for multiple cross-reactive epitopes. Am J Pathol 1991;138:285-301.

27. Malkiel S, Liao L, Cunningham MW, et al. T-cell-dependent antibody response to the dominant epitope of streptococcal polysaccharide, $\mathrm{N}$-acetyl-glucosamine, is cross-reactive with cardiac myosin. Infect Immun 2000;68:5803-5808.

28. Oliveira DBG. Poststreptococcal glomerulonephritis: getting to know an old enemy. Clin Exp Immunol 1997;107:8-10.

29. Poon-King R, Bannan J, Viteri A, et al. Identification of an extracellula plasmin binding protein from nephritogenic streptococci. J Exp Med 1993;178:759-763.

30. Rodriguez-Iturbe B, Batsford S. Pathogenesis of poststreptococcal glomerulonephritis a century after Clemens von Pirquet. Kidney Int 2007;71:1094-1104.

31. Yoshizawa N, Oshima S, Takeuchi A, et al. Experimental acute glomerulonephritis induced in the rabbit with a specific streptococca antigen. Clin Exp Immunol 1997;107:61-67.

32. Batsford SR, Mezzano S, Mihatsch M, et al. Is the nephritogenic antigen in post-streptococcal glomerulonephritis pyrogenic exotoxin B (SPE B) or GAPDH? Kidney Int 2005;68:1120-1129.

33. Cu GA, Mezzano S, Bannan JD, et al. Immunohistochemical and serological evidence for the role of streptococcal proteinase in acute post-streptococcal glomerulonephritis. Kidney Int 1998;54:819-826.

34. Parra G, Rodriguez-Iturbe B, Batsford S, et al. Antibody to streptococca zymogen in the serum of patients with acute glomerulonephritis: a multicentric study. Kidney Int 1998;54:509-517.

35. Luo YH, Kuo CF, Huang KJ, et al. Streptococcal pyrogenic exotoxin B antibodies in a mouse model of glomerulonephritis. Kidney Int 2007;72:716-724.

36. Chen CY, Luo SC, Kuo CF, et al. Maturation processing and characterization of streptopain. J Biol Chem 2003;278: 17336-17343.

37. Kuo CF, Luo YH, Lin HY, et al. Histopathologic changes in kidney and liver correlate with streptococcal pyrogenic exotoxin B production in the mouse model of group A streptococcal infection. Microb Pathog 2004;36:273-285.

38. Ades EW, Candal FJ, Swerlick RA, et al. HMEC-1: establishment of an immortalized human microvascular endothelial cell line. J Invest Dermatol 1992;99:683-690.

39. Shikhman AR, Greenspan NS, Cunningham MW. A subset of mouse monoclonal antibodies cross-reactive with cytoskeletal proteins and group A streptococcal M proteins recognizes $N$-acetyl- $\beta$-Dglucosamine. J Immunol 1993;151:3902-3913.

40. Frank R. The SPOT-synthesis technique. Synthetic peptide arrays on membrane supports-principles and applications. J Immunol Methods 2002;267:13-26.

41. Song $C Y$, Chen $W L$, Yang MC, et al. Epitope mapping of a monoclonal antibody specific to bovine dry milk. Involvement of residues 66-76 of strand $\mathrm{D}$ in thermal denatured $\beta$-lactoglobulin. J Biol Chem 2005;280:3574-3582

42. Simon A, Wilhelmi M, Steinhoff $G$, et al. Cardiac valve endothelial cells: relevance in the long-term function of biologic valve prostheses. J Thorac Cardiovasc Surg 1998;116:609-616.

43. Kaplan $M H$, Bolande R, Rakita L, et al. Presence of bound immunoglobulins and complement in the myocardium in acute rheumatic fever. Association with cardiac failure. $\mathrm{N}$ Engl J Med 1964;271:637-645.

44. Kaplan MH. Autoantibodies to heart and rheumatic fever: the induction of autoimmunity to heart by streptococcal antigen cross-reactive with heart. Ann NY Acad Sci 1965;124: 904-915.

45. Zabriskie JB, Freimer EH. An immunological relationship between the group A streptococcus and mammalian muscle. J Exp Med 1966;124:661-678.

46. Zabriskie JB, Hsu KC, Seegal BC. Heart-reactive antibody associated with rheumatic fever: characterization and diagnostic significance. Clin Exp Immunol 1970;7:147-159.

47. Dudding BA, Ayoub EM. Persistence of streptococcal group A antibody in patients with rheumatic valvular disease. J Exp Med 1968;128. 1081-1098.

48. Cunningham MW, Swerlick RA. Polyspecificity of antistreptococcal murine monoclonal antibodies and their implications in autoimmunity. J Exp Med 1986;164:998-1012.

49. Cunningham MW, Hall NK, Krisher KK, et al. A study of anti-group A streptococcal monoclonal antibodies cross-reactive with myosin. J Immunol 1986;136:293-298.

50. Cunningham MW, McCormack JM, Talaber LR, et al. Human monoclonal antibodies reactive with antigens of the group $A$ streptococcus and human heart. J Immunol 1988;141:2760-2766.

51. Shikhman AR, Greenspan NS, Cunningham MW. A subset of mouse monoclonal antibodies cross-reactive with cytoskeletal proteins and group A streptococcal M proteins recognizes $N$-acetyl-beta-Dglucosamine. J Immunol 1993;151:3902-3913.

52. Shikhman AR, Cunningham MW. Immunological mimicry between $\mathrm{N}$-acetyl-beta-D-glucosamine and cytokeratin peptides. Evidence for a microbially driven anti-keratin antibody response. J Immunol 1994;152:4375-4387

53. Sapru RP, Ganguly NK, Sharma S, et al. Cellular reaction to group A beta-haemolytic streptococcal membrane antigen and its relation to complement levels in patients with rheumatic heart disease. Brit Med J 1977;2:422-424.

54. Leask RL, Jain N, Butany J. Endothelium and valvular diseases of the heart. Microsc Res Tech 2003;60:129-137. 
55. Galvin JE, Hemric ME, Ward K, et al. Cytotoxic mAb from rheumatic carditis recognizes heart valves and laminin. J Clin Invest 2000;106:217-224.

56. Cunningham MW. Molecular mimicry, autoimmunity and infection in the pathogenesis of rheumatic fever. Int Congress Series 2006;1289:14-19.

57. Goldstein I, Halpern B, Robert L. Immunological relationship between streptococcus A polysaccharide and the structural glycoproteins of heart valve. Nature 1967;213:44-47.

58. Turner JR, Tartakoff AM, Greenspan NS. Cytologic assessment of nuclear and cytoplasmic O-linked $\mathrm{N}$-acetylglucosamine distribution by using anti-streptococcal monoclonal antibodies. Proc Natl Acad Sci USA 1990;87:5608-5612.

59. Pockley AG. Heat shock proteins, inflammation, and cardiovascular disease. Circulation 2002;105:1012-1017.
60. Tontsch D, Pankuweit S, Maisch B. Autoantibodies in the sera of patients with rheumatic heart disease: characterization of myocardial antigens by two-dimensional immunoblotting and $\mathrm{N}$-terminal sequence analysis. Clin Exp Immunol 2000;121: 270-274.

61. Olive C. Progress in M-protein-based subunit vaccines to prevent rheumatic fever and rheumatic heart disease. Curr Opin Mol Ther 2007;9:25-34.

62. Batzloff MR, Pandey M, Olive $C$, et al. Advances in potential M-protein peptide-based vaccines for preventing rheumatic fever and rheumatic heart disease. Immunol Res 2006;35:233-248.

63. Kuo CF, Wu JJ, Lin KY, et al. Role of streptococcal pyrogenic exotoxin B in the mouse model of group A streptococcal infection. Infect Immun 1998;66:3931-3935. 